\title{
KESADARAN DARI SEBATANG BAMBU Estetika Zen pada Film Animasi The Tale of Princess Kaguya
}

\author{
Galuh Sekartaji \\ Mahasiswa Pascasarjana \\ Institut Seni Indonesia Yogyakarta \\ ntungberanaksapi8@gmail.com
}

\begin{abstract}
The Tale of Princess Kaguya by Studio Ghibli has mesmerized the audience with its success in narrating a serious and tragic story in a feminine and beautiful way by adapting traditional Japanese watercolor painting art. The choice to employ such specific visual style must be based on certain reasons other than merely foregrounding cultural identity. This thesis aims at understanding the concept of humanity offered by this visual style by conducting a comprehensive analysis on the visual aspect, narrative, and characterisation of this piece of art observed through Zen aesthetics which is rooted on the principles of Buddhism. The conflict in this animation portrays various manifestations of both love and criticism towards social classes. Gentleness, modesty, and depth are Zen characteristics which are depicted through the color nuance. Some of the newly presented characters have succeeded in strengthening the idea of humanity, while the others do not serve well to build the humor and satire because of the overly strong melancholic atmosphere. The main element in building the dimension of feeling appears to be the simplest element in visual arts, namely lines and colors which successfully communicate the main character's emotional aspects. The basic idea of this piece of art is the life cycle of a bamboo tree, a human being who trying to find her truth of freedom and is rooted deeply on her nature, which is manifested in the character of Kaguya. This animation is a representation of a meditation process where a subject is continuously learning herself until she reaches the enlightenment.
\end{abstract}

Keywords: Kaguya, animation, aesthetics, Zen, humanity, bamboo, visual storytelling.

Relevance to Visual Communication Design Practise: this research contributes to the understanding on how the visual language in an animation is able to narrate an idea in a good and balanced way in accrodance to the narrative aspects without reducing the aesthetics of the work. This research also enriches the discourses and researches in the field of Visual Communication Design by employing Eastern aesthetics approach.

\section{PENDAHULUAN}

Setiap karya seni memiliki cara bertuturnya sendiri, begitu pula karya animasi. Studio Ghibli menyuguhkan karya film animasi yang reflektif dan memukau yaitu The Tale of Princess Kaguya. Karya ini disutradarai dan skenarionya disusun oleh Isao Takahata, salah satu anggota Studio Ghibli. Pria kelahiran Ise, 29 Oktober 1935 ini berpengalaman sebagai penulis skenario, sutradara, dan animator, produser di Studio Ghibli. Kaguya merupakan karya ke limanya yang meraih banyak apresiasi. Berbeda dengan Miyazaki dengan gaya fantasinya, Takahata terinfluense dengan aliran neorealisme yang mana ia selalu mempertimbangkan detail karyanya jika disandingkan dengan kehidupan sehari-hari, terutama mengangkat tema kemanusiaan.

Kemanusiawian adalah konsep yang ditekankan Takahata dalam karya kelimanya 
ini, dimana ia menerapkannya melalui proses penciptaan karyanya, bahasa visual, narasi dan pembangunan karakternya. Salah satunya adalah pemilihan gaya visual yang diadaptasi dari seni kaligrafi Jepang, dalam artian outline yang menyerupai goresan kuas dan warna opaque menjadi bahasa "rasa" yang menguatkan nuansa cerita tersebut. Hal tersebut memberi angin segar bagi dunia animasi, terutama 2 dimensi, yang mana Ghibli mampu menanamkan identitas kultural melalui kekuatan visual pada persepsi penontonnya.

Kaguya sebagai karakter seorang putri setengah dewa digambarkan sebagai gadis yang bebas, sederhana, dan mandiri. Karakter tersebut bertolak belakang dengan karakter putri karya Walt Disney yang cukup populer dengan kelemahlembutannya dan keberadaan pangeran yang menolongnya. Interpretasi tokoh Kaguya tidak berhenti sampai karakter saja, namun situasi tokoh disampaikan pula melalui unsur-unsur visual tiap adegan pastinya memiliki alasan. Puteri adalah simbol panutan bagi perempuan, yang dalam film ini digambarkan sebagai karakter yang merakyat sekaligus pemegang keputusan. Karakter Kaguya digambarkan lebih kuat dan teguh dari versi asli kisah tersebut yang tentunya memiliki korelasi terhadap fenomena masyarakat di Jepang saat ini.

Jika diamati melalui kacamata feminis, Kaguya merupakan satu bentuk kritik feminisme terhadap posisi perempuan dalam sebuah cerita, yaitu sebagai pemegang kendali. Namun tulisan ini ingin menginterpretasikan ulang makna kemanusiaan tidak hanya sebatas posisi perempuan dan laki-laki, namun secara keseluruhan meliputi moral, kritik sosial, dan spiritual melalui nilai estetika Zen ${ }^{1}$.

Tulisan ini mencoba mengkaji makna kemanusiaan dalam karya animasi Kaguya melalui estetika Zen dengan pertimbangan: 1) memiliki konsep keindahan yang sama-sama berakar dari Buddhisme, 2) Zen sebagai aliran spiritualitas yang lama dianut mayoritas masyarakat Jepang sehingga mendekati gagasan kolektif kemanusiaan masyarakat Jepang. Harapannya, tulisan ini mampu mengupas lebih dalam ide dasar, kritik dan cara penyampaian pada karya ini terutama dari segi bahasa visualnya.

\section{METODE}

"Segala emelen dari garis, bentuk, warna,nilai, dan gerakan pada pembuatan film animasi mengarah pada pengkomunikasian ide yang sebenarnya." (Gotot Prakosa, 2010 : 352)

Penelitian ini menggunakan pendekatan estetik dari sisi filsafat seni ${ }^{\mathrm{i}}$ yang dalam kajiannya, segala aspek dalam karya desain memiliki makna simbolik, sosial, budaya, keindahan, penyadaran maupun religius. Estetika tidak hanya memahami karya sebatas keindahan dalam arti konvensional melainkan bergeser ke arah wacana dan fenomena. Melalui pendekatan tersebut, nilai keindahan dalam karya desain

\footnotetext{
${ }^{1}$ Kata Ali, M. (2011). ESTETIKA : Pengantar Filsafat Seni: 153-154. turunan dari bahasa Mandarin Cha'an yang artinya meditasi. Zen dianggap sebagai ajaran agama dan filsafat yang berakar dari ajaran Buddhisme Mahayana. Pertama kali dibawa ke Tiongkok pada abad ke 6 oleh Boddhidarma dari India, lalu berkembang pada masa Dinasti T'ang hingga dinasti Sung dan Yuan (618-1279). Ajaran Zen masuk ke Jepang pada masa Kamakura sampai awal masa Edo (11851236). Ajaran Zen membawa pengaruh bagi kesenian, kehidupan militer, dan kehidupan sehari-hari masyarakat Jepang.
} 
bukan sekedar pelengkap namun memiliki makna simbolis yang luas diantaranya nilai spiritual, moral, dan etika ${ }^{\text {ii. }}$ Aspek yang akan dikaji meliputi narasi, karakter, teknik penyampaian, proses kreasi dan elemenelemen visual yang ada dalam adegan. Nilainilai Zen menjadi landasan menelaah ide dasar yang menjadi pesan utama dalam karya animasi ini. Penelitian ini juga menyertakan persepsi penciptanya. Lebih lanjut penulis mencoba masuk dalam perspektif subyek utama karya ini yaitu tokoh Kaguya dan dikaitkan dengan fenomena masyarakat saat ini.

\section{ESTETIKA ZEN}

Alam menjadi titik estetika di Jepang, karena alam yang mengisi hampir semua obyek seni di Jepang sekaligus memperdalam antara religiusitas dan semangat hidup ${ }^{\text {iii }}$. Ajaran Buddha juga menekankan kesederhanaan dan menyelaraskan diri dengan alam yang menjadi fondasi dari Zen. Zen merupakan ajaran spiritual berakar dari Buddhisme yang berkembang di Jepang dan menjadi salah satu nilai estetika Timur sampai saat ini.

Ada 3 ajaran dasar Buddhisme yang merupakan ringkasan tentang pengetahuan yang benar berkaitan tentang kodrat dan hakikat hidup yang mendasari Zen. Tiga ajaran dasar ini disebut Tiga Tanda Sang Wujud (Ti-Lakkhana), yaitu: 1) Penderitaan (dukkha) bahwa setiap makhluk yang menjalani kehidupan pasti mengalami derita (lahir, usia tua, kesakitan, kematian) yang sumbernya dari nafsu inderawi; 2) Ketidakkekalan (anicca) bahwa segala yang ada didunia bersifat sementara; 3) Ketanpadirian (anatta) yaitu diri sebenarnya adalah kosong, wadag. Hal ini mengarahkan bahwa Buddha menyangkal eksistensi diri (ego-self).

Keindahan bagi Zen adalah sebuah esensi kemurnian (pure) yang mengarah pada kodrat dan hakikat semua makhluk hidup, terutama manusia. Kesempurnaan, kesucian, formal bukanlah keindahan bagi Zen karena justru menjauhkan diri dari yang ideal dan membuat orang justru terikat pikirannya dan memunculkan nafsu untuk memperoleh sesuatu ${ }^{\text {iv }}$.

Wabi sabi menjadi salah satu konsep estetika Jepang yang berkaitan dengan spiritualitas Zen. Wabi dapat diartikan sunyi, sepi , dan sederhana, miskin ${ }^{2}$ dalam artian positif, berkaitan dengan ruang. Sabi diartikan sebagai menua, berkaitan dengan waktu. Tadao Ando menjelaskan wabi sabi adalah mencari makna keindahan dalam ketidaksempurnaan dan kedalaman pada alam, dari keadaan menua secara alamiah,terurai dan punah $^{\mathrm{v}}$. Konsep ini berpusat pada penerimaan ketidakkekalan dan ketidaksempurnaan sebagai sifat kehidupan.

Konsep wabi-sabi berkembang menjadi corak karya seni di Jepang. Shinichi Hisamatsu, seorang ahli upacara minum teh Jepang, mengemukakan ada 7 ciri utama karya seni Zen yang mewakili ajaran Zen yaitu:

1) Fukinsei (asimetris): ketidakteraturan, berkelok-kelok dan tidak seimbang, membuang hawa nafsu yang berorientasi

\footnotetext{
${ }^{2}$ Miskin diartikan lepas dari sifat materialistik, merujuk pada sikap kesederhanaan.
} 
pada yang ideal. Kesempurnaan adalah menerima ketidaksempurnaan itu sendiri.

2) Kanso (kesederhanaan): tidak rumit, tidak mencampuradukkan sesuatu.

3) Kokou (sublimitas yang keras ${ }^{3}$ ): “menjadi kering", yang berarti hilangnya sifat kekanak-kanakan, ketidakterampilan, ketidakberpengalaman, dan yang tesisa adalah intisari atau esensi.

4) Shizen (alamiah): kewajaran, tidak dibuat-buat. Bagi seniman adalah menyatu dengan karya yang diciptakan, tidak ada lagi jarak.

5) Yuugen (kedalaman dan kehalusan): wujud pengendapan rasa, perenungan yang dalam, esensi. Dalam kedalaman tersebut ada unsur kegelapan yang dapat diasosiasikan negatif seperti kehancuran, membawa kesuraman, rasa takut. Namun kegelapan juga diasosiasikan positif dan sering disebut kegelapan yang tenang.

6) Datsuzoku (bebas dari kemelekatan): tidak tergantung pada sesuatu, baik itu aturan atau hal lain. bebas dalam Zen maksudnya tidak terbelenggu namun keluwesan terhadap aturan yang berlaku.

7) Seijaku (ketenangan): gerak yang tidak mengganggu. Namun secara negatif mampu dimaknai sebagai tidak dibuat gelisah, atau tidak dalam gelisah. Kegelisahan juga penting dalam menggali diri, namun tetap dihadapi dengan ketenangan.

\footnotetext{
${ }^{3}$ Ibid , h. 163. Menurut Shinichi Hisamatsu dalam Zen and the Fine Arts : Sublimitas yang keras berarti tanpa sensualitas, terbebas dari indera-indera. Dan terkait dengan "Diri Tanpa Bentuk". Sifat ini juga bisa dimaknai menjadi "tidak tersekat".
}

Nilai-nilai estetika Zen tersebut membentuk proses kreasi yang bersifat meditatif, mengedepankan rasa dan intuisi, sekaligus membentuk ciri khas karya seni dan budaya Jepang yang minimalis, dan jauh dari sifat gemerlap, berlebihan, mencolok ${ }^{\mathrm{vi}}$.

\section{Data Objek}

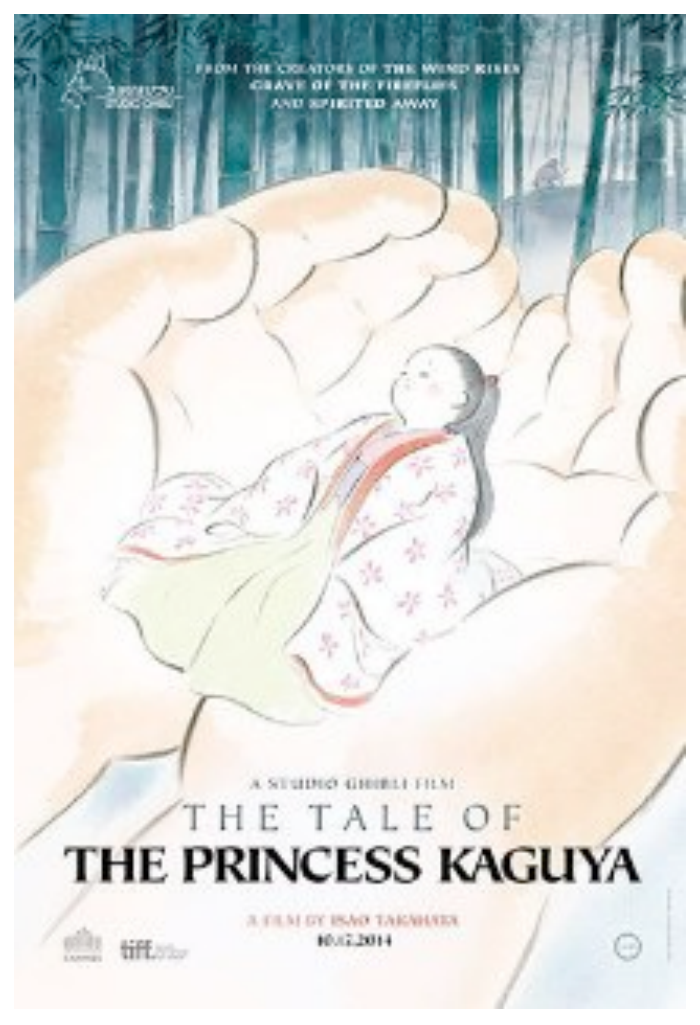

Gambar 1 The Tale of Princess Kaguya Cover Sumber : dokumentasi pribadi

Judul : The Tale of Princess Kaguya (Kaguya Hime no Monogatari)

Genre : Drama Legenda

Durasi : 02:17.13

Produksi : Studio Ghibli, Jepang

Sutradara : Isao Takahata

Sinopsis : Sepasang kakek dan nenek yang hidup sebagai pengrajin bambu di bukit menemukan seorang putri mungil yang keluar dari sebatang bambu bercahaya. Mereka merawatnya seperti anak sendiri. 
Keberadaan Kaguya menjadi berkah bagi kakek dan nenek tersebut karena mereka mendapat harta dari sebatang bambu, yang menjadikan mereka kaya raya dan pindah ke kota. Kaguya tumbuh menjadi putri yang cantik dan pandai bermain dawai hingga terdengar di semua kalangan. Para bangsawan hingga Kaisar melamarnya dengan segala cara namun ditolaknya. Kaguya merasa terpenjara dengan kemewahan menderita dan memohon pada bulan untuk membawanya kembali. Ia sadar bahwa ia adalah putri dari bulan yang diutus ke dunia untuk menjalani karma sekaligus menolong manusia yang mengalami penderitaan. Pada umur 15 tahun saat bulan purnama, Kaguya dijemput oleh Buddha dan para bidadari bulan untuk kembali ke bulan meninggalkan Kakek dan Nenek.

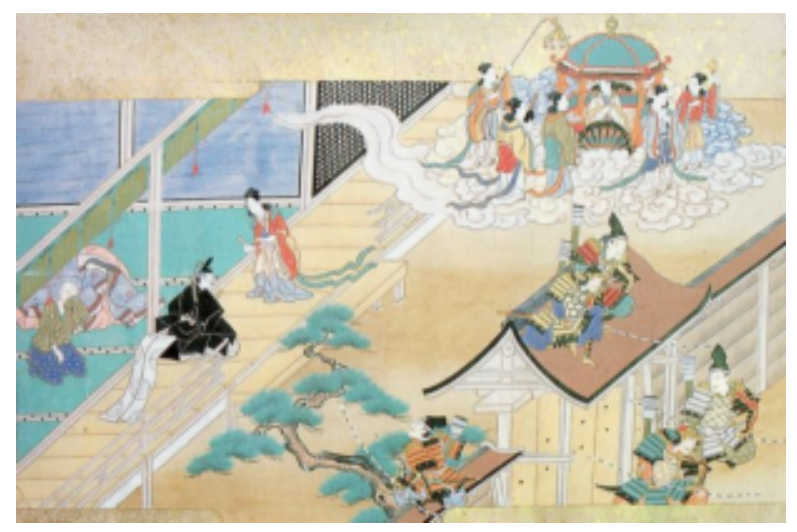

Gambar 2 Ilustrasi dari naskah asli Kaguya Hime Sumber: wikipedia

Karya ini merupakan adaptasi dari dari dongeng legendaris Jepang berjudul Kaguya Hime no Monogatari (Kisah Putri Kaguya) atau juga dikenal dalam judul Taketori no Okina no Monogatari (Kisah Kakek Pengambil Bambu). Kisah ini diperkirakan berasal dari awal zaman Heian dimana si pengarang, yang belum diketahui namanya, sangat memahami gaya sastra Tiongkok maupun agama Buddha. Karya asli ini berbentuk prosa panjang, dengan tema cerita anti kemapanan. Kisah ini adalah kisah fiksi, namun beberapa tokoh bangsawan yang melamar Kaguya dalam kisah tersebut dipercaya mendekati karakter para bangsawan jaman itu.

Menurut Charlie Kaufman sensibilitas ${ }^{4}$ sangat berpengaruh dalam interpretasi dan karya adaptasi. Isao Takahata sebagai sutradara dan penulis naskah memiliki sensibilitas terhadap fenomena "kemanusiaan" dan kisah-kisahnya cenderung realistis dengan menghadirkan benda-benda maupun setting yang tidak jauh beda dari tempat nyata.

Proses pembuatan animasi ini memakan waktu 8 tahun dengan melibatkan para kreator senior. Joe Hisaisi sebagai penggarap musiknya melibatkan orkestra asli dan instrumen tradisional Jepang. Animasi ini ditujukan untuk remaja sampai dewasa, karena bobot cerita dan penyampaiannya cenderung berat. Langkah pembuatannya sama seperti pembuatan animasi biasanya yaitu konsep dasar (pra produksi), skript, desain karakter, dubbing, storyboard - rough layout-key-inbetween, editing (produksi). Yang menjadi pembedaan antara lain: 1) proses dubbing dilakukan hanya berbekal naskah dan tanpa unsur visual apapun ${ }^{5}$. 2) proses clean-up ${ }^{6}$ dan colouring karakter menggunakan komputer seperti pembuatan

\footnotetext{
4 Sensibilitas bisa diartikan kemampuan merasakan, memahami subyek, dan melibatkan intuisi.

5 www.celestialkitsune.wordpress.com. Dubbing adalah pengambilan suara dalam animasi untuk menentukan timing dan keypose pada proses selanjutnya. Biasanya dubbing disertai dengan storyboard atau desain karakter.

${ }^{6}$ Proses membetulkan detail gambar yang dibuat para animator sehingga garis menjadi bersih di layar karena biasanya gambar para animator masih berupa sketsa kasar.
} 
My Neighbors The Yamadas, berbeda dengan karya Ghibli umumnya menggunakan cell animation vii . 3) menitikberatkan pada eksplorasi dan detail gerak yang realis.

Sutradara berperan dalam memberikan visi dan artistik dalam sebuah film animasi. Ia juga harus mengenal karakter yang akan dibuat dengan baik dan menentukan interpretasi visual skenario sesuai dengan

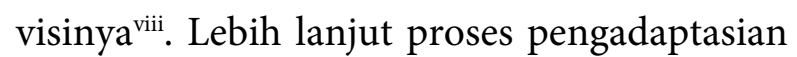
narasi berupa prosa panjang ke dalam film animasi pastinya mengalami perubahan sesuai konteksnya. Menurut Linda Hutcheon mengadaptasi karya verbal (narasi) ke visual (animasi) diperlukan unsur dramatisasi ${ }^{\text {ix }}$, karena setiap pembaca memiliki imajinasi yang kadang tidak terjelaskan, sehingga konsep (visi) sutradara yang bersifat abstrak harus dapat dirasakan melalui mata dan pendengaran. Dalam Zen, dramatisasi dapat dimaknai sebagai kokou (menjadi kering) yaitu kemampuan menampakkan karakteristik alami dari subyek. Karakteristik alami diartikan sebagai esensi, dalam konteks proses kreasi berarti visi (konsep dasar) Sutradara.

\section{NARASI}

Untuk menggubah narasi, kreator harus memahami dasar dari kisah yang akan diubah, bagian mana yang akan dimainkan. Kreator yang juga sebagai pembaca narasi harus menemukan titik punctum ${ }^{7}$ pada kisah tersebut. Tema kesederhanaan dan anti kemapanan menjadi konsep dasar dari kisah

\footnotetext{
${ }^{7}$ Titik yang mendebarkan. Pertanyaan yang ingin dijawab dari cerita sebelumnya oleh interpreter. Titik punctumlah yang menentukan pendistorsian cerita.
}

aslinya yang juga menjadi ajaran hidup Buddhisme.

Karya animasi ini tergolong tidak terlalu banyak dialog dibandingkan animasi Jepang yang lain. Dialog disampaikan melalui narator dan selebihnya dialog para tokoh yang menjadi dialog kembangan dari pesan utama. Meski sedikit, dialog yang disampaikan cukup tegas menyampaikan pesan utama yang terdapat pada beberapa adegan inti. Selebihnya, narasi disampaikan dengan unsur musik dan ilustrasi adegan yang kuat.

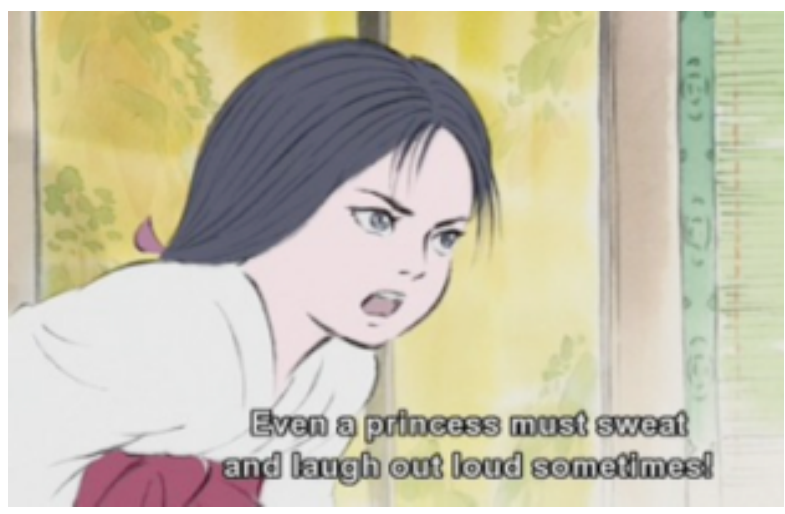

\footnotetext{
Gambar 3 Contoh dialog utama yang cukup menjelaskan pesan utama Sumber : dokumentasi pribadi
}

Adapun penjabaran alur cerita secara garis besar meliputi :

1) Eksposisi: awal cerita dimulai, pengenalan tokoh. Dimulai dengan pertemuan Kakek dan Kaguya di hutan bambu dan menjadi kebahagiaan bagi Kakek dan Nenek. Babak ini menggambarkan bagaimana alam dan kesederhanaan di desa membentuk pribadi Kaguya.

2) Konflik: permasalahan awal yang dibangun. Dimulai dari perpindahan keluarga Kaguya dari desa ke kota. Harta benda yang 
didapatkan Kakek dari bambu mendorongnya untuk memperlakukan Kaguya sebagai Putri bangsawan. Ini adalah gambaran mentalitas manusia terhadap harta benda, bagaimana harta dan status sosial mampu merubah orientasi sang Kakek dari seorang bersahaja menjadi orang yang mendewakan egonya dan justru menjauhkan Kaguya dari kebahagiaanya yang sebenarnya.

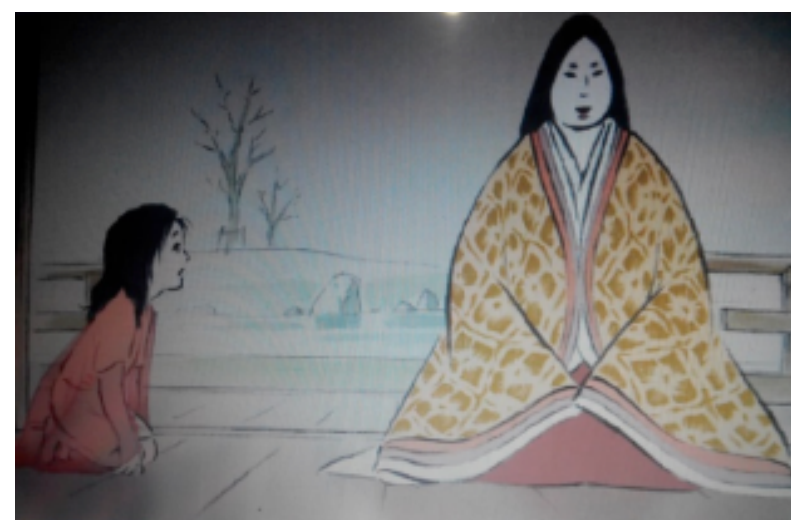

Gambar 4 Kehadiran Lady Sagami menjadi perbandingan tentang imaji perempuan Sumber : dokumentasi pribadi

3) Komplikasi : gesekan yang terjadi di setiap babak yang melibatkan pihak atau permasalahan lain yang menggiring ke krisis utama. Kehadiran Lady Sagami sebagai guru tatakrama dan simbol wanita ideal jaman itu berseberangan dengan karakter alamiah Kaguya. Gesekan terjadi pada wilayah ideologi tentang imaji perempuan sempurna, antara yang artifisial (Lady Sagami) dengan yang essensial (Kaguya). Kekecewaan memuncak ketika ia menyadari bahwa kehendaknya semakin berseberangan dengan kehendak sang Kakek namun ia tetap menurutinya. Gesekan mengenai kesadaran kasta terjadi melalui munculnya Sutemaru yang mencuri ayam, dan orang desa yang memohon ampun padanya atas kesalahan yang sebenarnya tidak dilakukannya.

4) Krisis : konflik utama atau puncak konflik. Puncak konflik batin Kaguya terletak saat ia menyadari bahwa orang sekitar memuja dirinya yang palsu. Terlebih sang Kakek yang tdaik menjalankan tanggung jawab sebagai orang tua ketika Sang Kaisar mencoba memeluk dan memboyongnya ke istana, meskipun gagal. Dari babak tersebut Kaguya mengenal ambisi manusia mampu mengubah bahkan merusak manusia lain. Di titik itulah Kaguya kehilangan kepercayaannya pada kehidupan di dunia dan ingin kembali ke bulan.

5) Resolusi : langkah penyelesaian. Dalam tiap permasalahan Kaguya dengan sang Kakek, Nenek memiliki peran penting sebagai penghibur dan pendengar dengan memberi ruang Kaguya mengekspresikan dirinya (yang sederhana). Ketika Kaguya mengabarkan kepergiannya, terdapat perbedaan cara mengatasinya antara Kakek dan Nenek. Kakek berusaha mencegah (prajurit dan beteng), namun Nenek menyerahkan keputusan pada hati Kaguya, ia hanya memberi kesempatan Kaguya untuk mengecap kembali alam pegunungan yang menjadi sumber kebahagiaannya. Dari keikhlasan itulah, Kaguya menemukan cintanya kembali dalam hidup, joy of life. (disimbolkan dengan bertemu Sutemaru).

6) Keputusan : akhir cerita. Segala cara tidak berhasil mencegah kepergian Kaguya. Saat akan berpisah Kaguya menemukan kesadaran bahwa segala yang ia keluhkan maupun kebahagiaanya tentang dunia adalah bentuk relief kehidupan. Sang Kakek sangat menyesal karena baru merasakan bahwa Kaguya adalah 
anaknya, berkah dari dewa, namun justru tidak dapat dijaganya.

Titik punctum pada cerita ini adalah kesedihan Kaguya, apa penyebab Kaguya menderita. Cerita asli menggambarkan Kaguya bersedih karena perpisahan dengan yang orangtua yang ia cintai ia akan kembali ke bulan, namun karya ini mengangkat sisi kemanusiaan Kaguya yang mempertanyakan hakekat kebahagiaan yang sesungguhnya.

Terdapat perbedaan detail cerita pada film ini dari kisah aslinya, diantaranya:

1) Kaguya berubah menjadi seorang bayi ketika disentuh oleh tokoh Nenek yang berperan sebagai ibunya.

2) Si Nenek mengalami keajaiban karena dapat memberikan asi di umurnya yang sudah tua.

3) Pada kisah asli, Kaguya dan Kaisar saling bertukar puisi sekaligus sebagai sarana penolakan atas lamarannya. Dalam film, Kaisar dan Kaguya tidak bertukar puisi, namun Kaisar mengirim surat lamaran pada Kakek. Kaguya menolak Kaisar secara langsung karena Kaisar diam-diam langsung memeluknya dari belakang. Ini menjadi puncak kekecewaan Kaguya terhadap sang Kakek, karena tidak melindunginya.

4) Kaguya digambakan memiliki cinta masa kecil, yaitu Sutemaru yang merupakan tokoh fiktif.

5) Ketika akan kembali ke bulan, Kaguya tidak meninggalkan apapun pada Kakek dan Nenek. Dalam kisah asli dikatakan Kaguya memberikan pil keabadian pada sang Kakek dan Nenek sebagai tanda terimakasih.

\section{Musim pada Narasi Visual}

Salah satu penerapan konsep wabi-sabi pada kebudayaan Jepang adalah menikmati pergantian musim. Setiap musim memberi makna sendiri dalam diri manusia. Banyak karya seni tradisional maupun modern menyampaikan pemaknaan 4 musim tersebut, termasuk animasi ini. 4 musim tersebut adalah musim semi (haru), musim panas (natsu), musim gugur (aki) dan musim dingin (fuyu).

Pemaknaan 4 musim ini disampaikan melalui narasi visual, yaitu relasi antar objek pada suatu adegan sekuensial yang memicu perasaan tertentu. Adapun objek-objek visual yang ditampilkan berupa burung,serangga, pepohonan, bunga dan benda alam lainnya. Pada beberapa peralihan babak, objek bunga mekar, kuncup, atau berbuah bukan hanya dtampilkan sebagai background, justru diletakkan pada titik jatuhnya pandangan sebagai bentuk pesan utama dalam adegan itu. Obyek-objek tersebut menjadi penghantar momen penting pada adegan berikutnya.

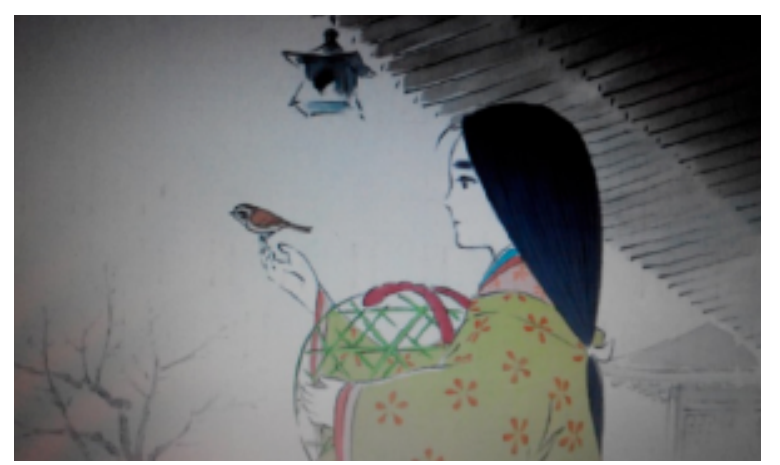

Gambar 5 Adegan melepas burung ditampilkan sebelum adegan datangnya lamaran para bangsawan. Sumber: dokumentasi pribadi

Bunga juga berfungsi menjelaskan makna dan relasi musim dengan tokoh Kaguya. Objek bunga banyak ditampilkan 
saat masa Kaguya kecil-remaja di desa untuk menandakan masa Joy of life karakter Kaguya. Di lain sisi, masa pendewasaan Kaguya yang menjadi masa kelam juga diawali dengan putaran musim yang sama. Latar kota tidak banyak menampilkan bunga, namun dengan burung yang menandakan semangat dan daya hidup. Maka pergantian musim dimaknai sebagai perputaran hidup. Berikut adalah pemaknaan musim dengan ilustrasi adegan nya :

1) Musim semi: awal harapan baru dimulai, dan merupakan awal bambu muda tumbuh $^{\mathrm{x}}$. Namun masa badai dan hujan datang yang dibarengi mekarnya sakura. Kejadian: Kedatangan Kaguya sebagai berkah, dan datangnya lamaran para bangsawan sebagai masa krisis Kaguya dewasa.

2) Musim panas: pengetahuan mulai nampak dan semangat untuk belajar dan bekerja $^{x i}$. Bunga menjadi buah, suara serangga mulai terdengar. Kejadian: Masa Kaguya bermain dan belajar bagaimana alam memberi hidup pada manusia.

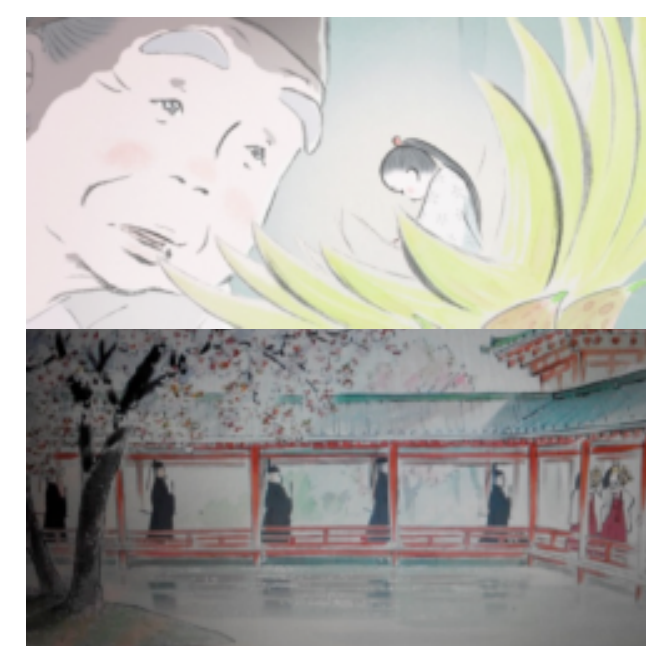

Gambar 6 Ilustrasi musim semi sebagai berkah (atas) dan dimulainya krisis (bawah) Sumber: dokumentasi pribadi

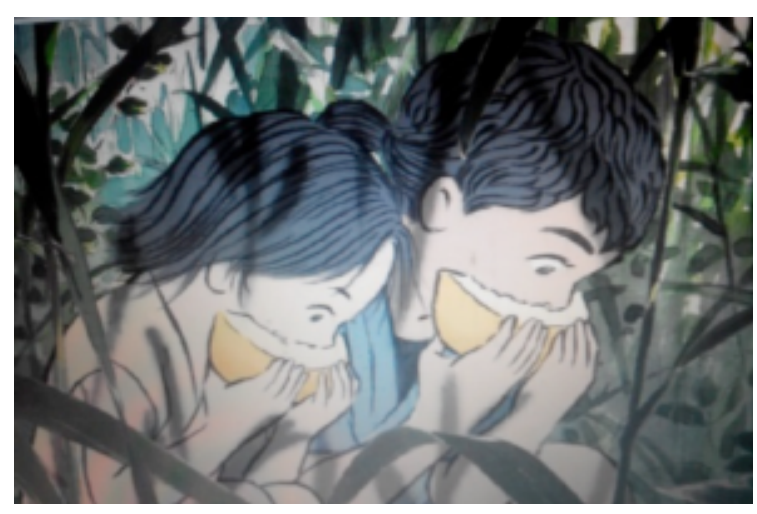

Gambar 7 Ilustrasi adegan Kaguya dan Sutemaru menikmati buah panenan musim panas.

Sumber: dokumentasi pribadi

3) Musim gugur : momen pengendapan kesedihan dan harapan yang tidak tersampaikan. Daun-daun gugur, burungburung mulai mencari tempat baru. Kejadian: Adegan burung yang mati diburu oleh teman-teman Kaguya menjadi penghantar babak Kaguya pindah ke kota dan menjalani kenyataan yang tanpa sadar mulai menggugurkan harapannya.

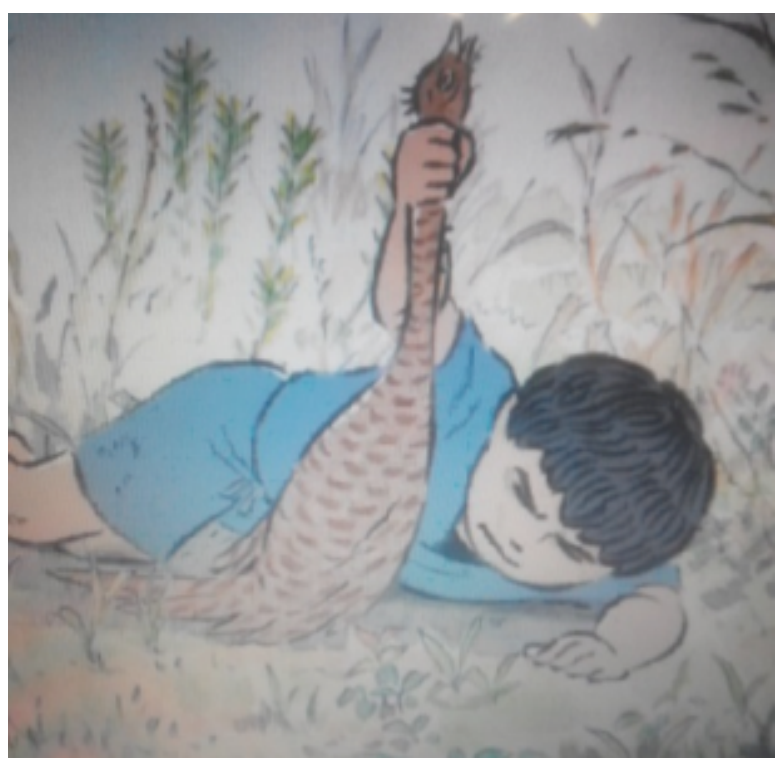

Gambar 8 Simbol burung mati, pertanda akan terjadi perpisahan dan matinya harapan. Sumber : dokumentasi pribadi 
4) Musim dingin: titik keheningan, masa menunggu dalam diam. Pohon mengering, dingin menusuk, bunga dan binatang tidak tampak, salju. Kejadian: Keputusasaan Kaguya yang merasa terkurung dan disepelekan oleh para bangsawan membawanya ke gunung bertemu dengan pembuat arang. Ia disadarkan tentang perputaran hidup, kehidupan setelah mati, dan pentingnya menunggu. Pada titik ini Kaguya mencoba "mengheningkan sisi pemberontaknya" dan menerima kehidupannya saat ini.
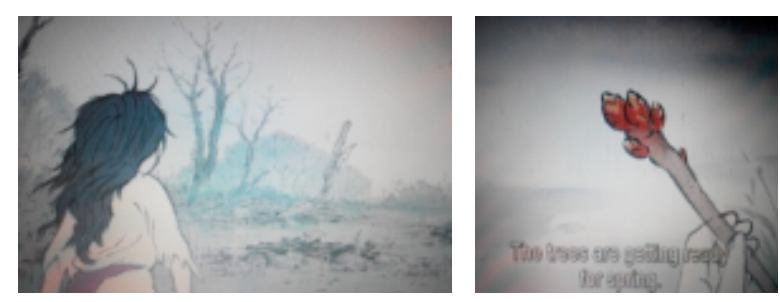

Gambar 9 Pohon kering dan tunas bunga baru yang mencerminkan keputusasaan dan harapan baru. Sumber : dokumentasi pribadi

\section{KARAKTER}

Karakter pada animasi ini terdiri dari karakter inti yaitu: Kaguya, Nenek, Kakek, Sutemaru. Karakter pendukung antara lain: Lady Sagami, para bangsawan, dayang, dan teman-teman lain. Pemaknaan karakter sebagai simbol berdasarkan hakikat Zen adalah diri sendiri (sang subyek) dan kesemuanya bukanlah sesuatu di luar diri kita, namun menjadi bagian yang menyusun dalam diri (semesta kecil). Maka masingmasing karakter merupakan bagian dalam unsur kepribadian Kaguya, mereka menyimbolkan apa yang ada dalam diri Kaguya yang tidak terpisahkan pada diri sang subjek.

\section{1) Kaguya}

Kaguya menjadi subyek yang dominan menggerakkan cerita. Secara garis besar, penggambaran tokoh Kaguya versi Takahata adalah seorang gadis yang memiliki pendirian kuat. Ia adalah gambaran gadis modern yang tinggal di jaman Heian ${ }^{\mathrm{xii}}$.

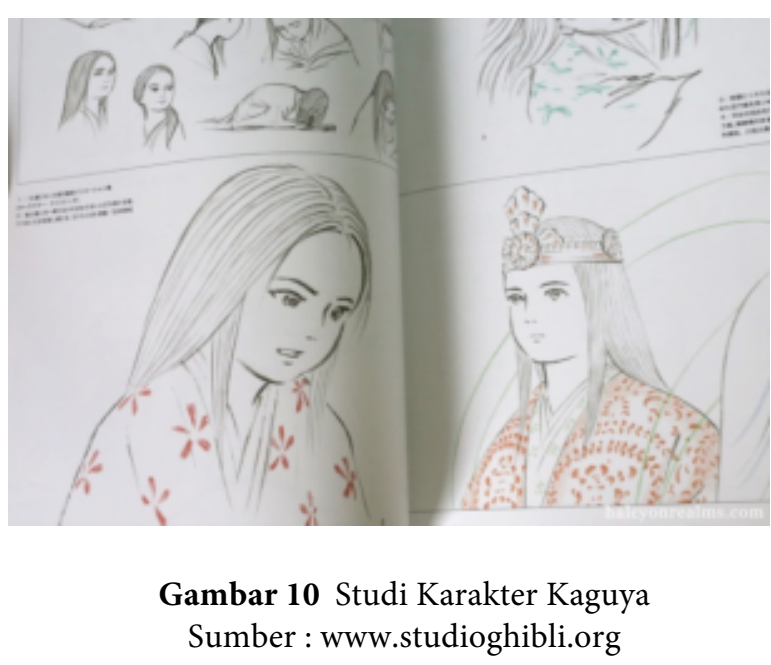

Kemagisan Kaguya disampaikan dalam bentuk sederhana, bukan terletak pada kekuatan gaib yang berlebihan ataupun atribut yang mencolok. Takahata tetap menghadirkannya semanusiawi mungkin. Aura magis tersebut terletak pada perpaduan shizen (alamiah), dan datsuzoku (bebas dari kemelekatan). Bagi persepsi karakter diluar dirinya, fukinsei dalam artian keganjilan yang alami, yaitu pertumbuhan yang jauh lebih cepat dari manusia pada umumnya. Maka ia dijuluki "bambu kecil", karena pertumbuhannya cepat seperti sebatang pohon bambu. 


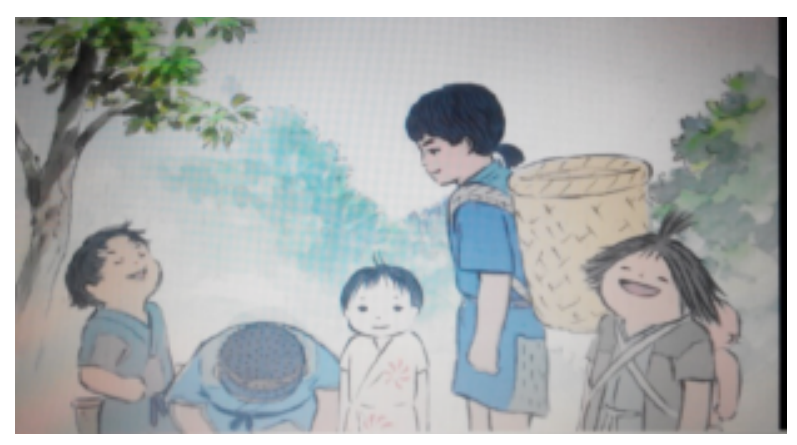

Gambar 11 Sosok Kaguya yang tampak lebih "cerah" dari teman-temannya di desa Sumber : dokumentasi pribadi

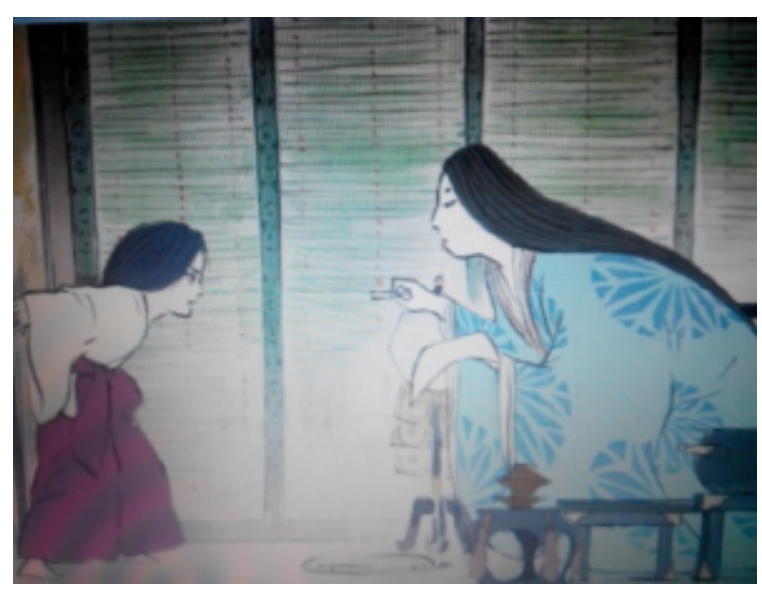

Gambar 12 Ilustrasi adegan yang menampakkan 3 ciri yaitu shizen, fukinsei dan datsuzoku Sumber : dokumentasi pribadi

Karakter Kaguya sebagai sosok wanita "modern" merujuk pada sikapnya yang berani mengutarakan pendapat. Namun ideologi yang dibawa olehnya jauh berbeda dengan "wanita modern" jaman ini, baik di Jepang maupun dunia. Sifat shizen (kealamiahan) menjadi ideologi yang ia bawa justru mencitrakan dirinya sebagai wanita yang konservatif. Ia meletakkan alam dan kealamiahan menjadi gaya dan tujuan hidup, yang dalam konteks saat ini justru tidak pernah menjadi obsesi orang modern. Datsuzoku Kaguya juga dipengaruhi oleh sifat shizennya yaitu ketika seseorang sudah menemukan dirinya, maka ia tidak akan mudah terbawa arus. Sifat fukinsei dalam artian tidak mengejar yang ideal (dalam artian artifisial), terletak pula pada pandangan Kaguya atas dirinya bukanlah manusia spesial/ gaib/ seorang dewi seperti imaji orang-orang terhadap dirinya. Ia merasa sama dengan individu lain yang mendambakan kebahagiaan, bahkan ia menyamakan dirinya seperti burung, serangga, atau makhluk hidup lain yang bebas menjadi dirinya secara alamiah. Subjek Kaguya adalah gambaran manusia yang menemukan esensi hidupnya melalui kealamiahannya, sehingga ia tidak akan mudah larut pada apa yang menjadi selera masyarakat, bahkan kekuasaan ${ }^{8}$ sekalipun, yang berseberangan dengan prinsipnya.

Orang modern terobsesi dengan kesempurnaaan (ideal menurut hukum manusia), fungsional, dan ketepatan. Kepraktisan justru menjauhkan mereka dari sesuatu yang sederhana dan alamiah karena kepraktisan memberi ruang luas dalam mewujudkan keinginan (duniawi) mereka, yang membuat mereka melangkah terlalu jauh dari keutamaan hidup sebagai contoh operasi plastik, dll. Maka nama Kaguya berarti cahaya terang dari sebatang bambu menjadi konsep dasar karakter Kaguya yang memiliki dimensi kritis sekaligus harapan bagaimana kehidupan seharusnya, apakah sumber kebahagiaan sesungguhnya, dan keutamaan hidup yang harus ditumbuhkan kembali.

\footnotetext{
${ }^{8}$ Disimbolkan dengan adegan keputusan Kaguya yang menolak secara tegas lamaran dari Kaisar. Kaisar sebagai simbol kekuasaan dan pengaruh yang besar.
} 


\section{2) Nenek}

Nenek berperan sebagai ibu Kaguya dan penetral kekontrasan Kakek dan Kaguya, kepribadiannya cair dan tidak menentang siapapun, ia paling memahami Kaguya. Karakter Nenek wujud sifat kanso (kesederhanaan) dan sheijaku (ketenangan) yang tidak mudah diubah oleh keinginan, terutama harta benda dan status sosial, ia tahu apa yang tepat baginya. Hal itu membuat keberadaannya menjadi penenang dan pendengar yang baik bagi Kaguya. Nenek adalah simbol "kata hati" Kaguya.

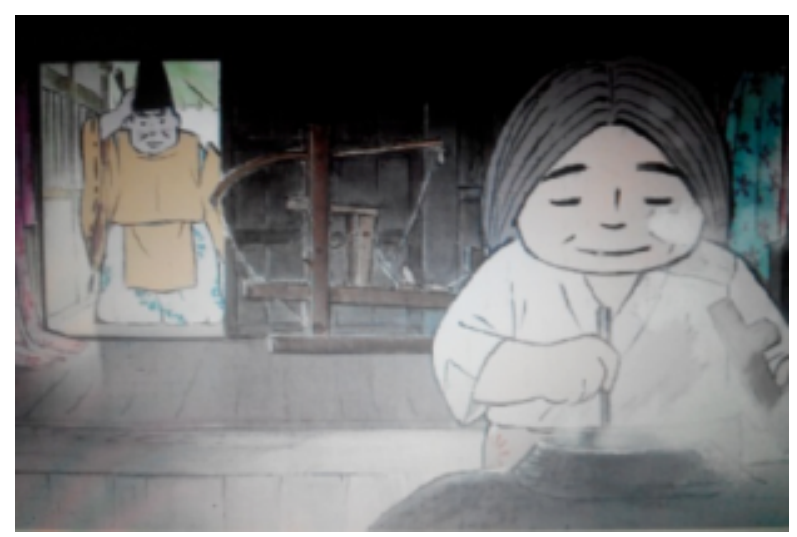

Gambar 13 Adegan Nenek yang tetap hidup sebagai orang desa di dalam istananya. Gambaran perbedaan Nenek dan Kakek.

Sumber : dokumentasi pribadi

\section{3) Kakek}

Karaktek kakek adalah menggambarkan seseorang yang keras kepala tapi mudah terbawa keadaan, terutama pengakuan orang. Baginya ukuran kebahagiaan adalah apa yang diluar dirinya dan yang menjadi harapan oranfg banyak yaitu harta, fasilitas, dan status sosial. Titik tolaknya ketika ia mendapatkan harta dari sebatang bambu yang ditujukan untuk hidup Kaguya, yang merubah persepsinya tentang hidup Kaguya bukan sebagai orang biasa namun seorang Putri raja. Secara fisik sifat Kakek yang berpandangan sempit dan egois ini digambarkan dengan mata sipit, raut kekanakan, ramah dan patuh.

Terdapat unsur satire pada karakter Kakek, yaitu topi kebesarannya sering tersangkut atap pintu sehingga membuatnya hampir terjatuh. Topi tersebut merupakan simbol status sosial dalam masyarakat. Kecenderungan tersebut bukan sekedar humor, namun tanda bahwa jabatan yang ia agungkan justru akan menjatuhkannya. Kakek adalah simbol dari pikiran, logika manusia yang tidak pernah bisa diam dan merasa cukup.
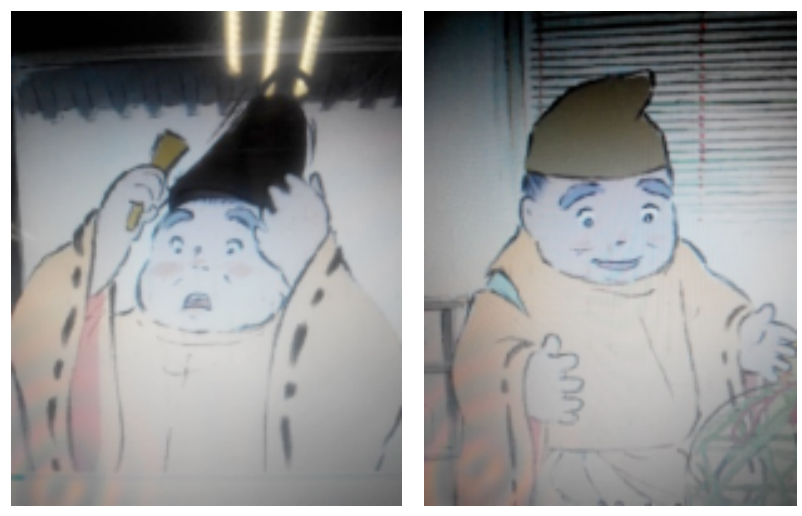

Gambar 14 Kakek hampir terjatuh karena topi tingginya tersangkut (kiri). Akhirnya ia mengenakan topi tukang bambu miliknya (kanan). Sumber : dokumentasi pribadi

\section{4) Sutemaru}

Sutemaru adalah tokoh fiktif yang tidak terdapat dalam kisah asli. Ia adalah sahabat masa kecil Kaguya yang saat dewasa mereka saling mencintai meski ia sudah memiliki anak dan istri. Sutemaru berasal dari keluarga mengrajin mangkuk kayu di gunung, ia digambarkan sebagai memiliki wibawa, berani, dan melindungi Kaguya. Secara fisik ia tampan daripada teman-teman desanya. Dan 
memiliki kemiripan dengan Kaguya, yaitu mata yang besar dan tatapan yang dalam. Sutemaru menjadi simbol dari cinta, gairah hidup, dan perlindungan. Di babak akhir, Sutemaru berperan meyakinkan Kaguya tentang rasa cinta dan perlindungan di bumi lewat keberadaannya.

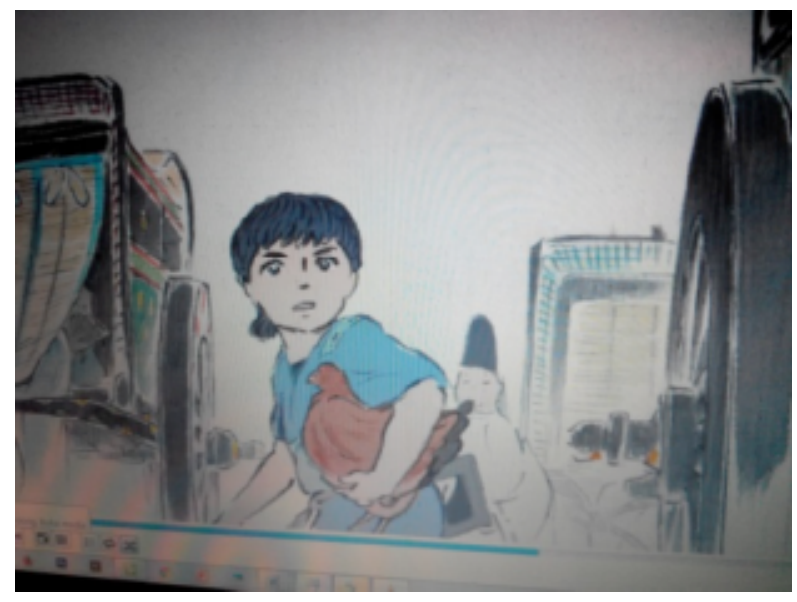

Gambar 15 Sutemaru sebagai tokoh tambahan. Adegan Sutemaru yang kabur karena mencuri ayam Sumber: dokumentasi pribadi

Adapun tokoh-tokoh pendukung dalam kisah ini yang menjadi kunci bergeraknya alur. Tukang pembuat arang adalah salah satu tokoh pendukung yang punya posisi penting dalam proses penyadaran Kaguya. Sekilas tukang pembuat arang secara fisik digambarkan seperti Bikhu, yaitu berkepala gundul dan rautnya tenang, namun dengan pakaian penduduk biasa. Tukang pembuat arang merupakan simbol kesadaran baru bagi Kaguya. Sang dayang kecil pendamping Kaguya juga menjadi tokoh fiktif yang digambarkan polos dan seperti anak-anak adalah simbol dari persahabatan, pelayanan. Lady Sagami dan para bangsawan dan Kaisar adalah simbol dari beragam obsesi akan keindahan, kesempurnaan, kecantikan, dan kekuasaan.

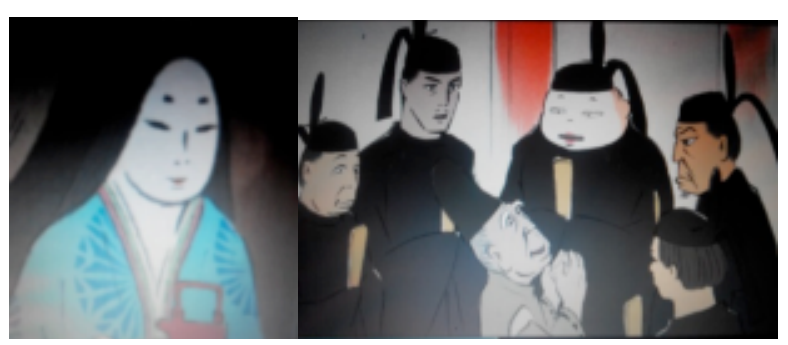

Gambar 16 (kiri-kanan) Lady Sagami, Para Bangsawan sebagai simbol obsesi duniawi. Sumber: dokumentasi pribadi
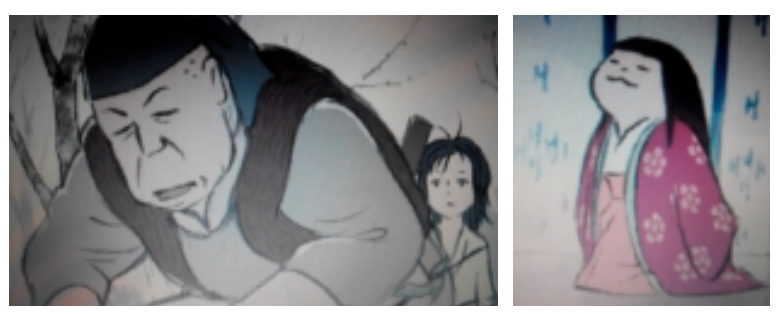

Gambar 17 (kiri-kanan) Tukang pembuat arang dan dayang kecil.

Sumber: dokumentasi pribadi

Visualisasi karakter tergolong sederhana namun cukup kuat dan detail menampilkan appeal (kesan yang diciptakan) melalui bentuk fisik, terutama mata, dan pakaian. Kaguya, Sutemaru, dan Nenek samasama bermata besar dan sorot teduh dan dalam, menggambarkan kecenderungan yang sama, yaitu shizen (kealamiahan) dan datsuzoku (bebas dari kemelekatan). Sifat shizen dapat berarti hidup dengan jujur sebagai manusia, apa adanya. Sifat itu melatih sensibilitas seseorang dalam menilai karakter yang lain, memahami esensi dan hakekat hidup sehingga ia memiliki pandangan luas dan dalam (mata besar). Pemahaman itu melatih pemikiran kritis dalam menilai hukum manusia, sehingga ia tidak akan mudah tunduk pada hukum maupun aturan 
yang sekiranya tidak adil atau semu (datsuzoku).
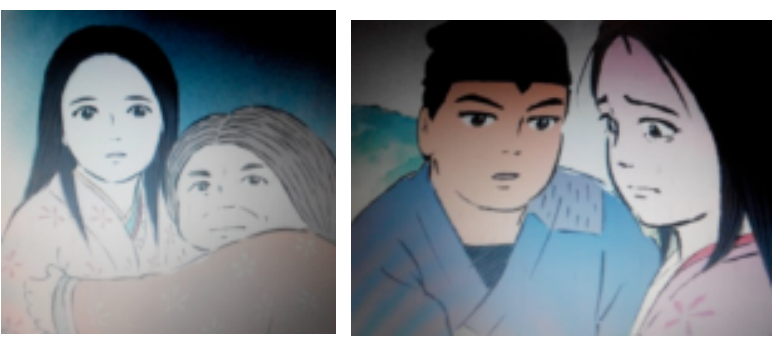

Gambar 18 (kiri-kanan) Penggambaran fisik yang setipe antara Kaguya-Nenek- Sutemaru, yaitu mata yang lebih besar dari tokoh lain. Keduanya adalah tokoh yang sepaham dengan ideologi Kaguya. Sumber : dokumentasi pribadi

Karakter bangsawan dibuat satire, perut besar, kumis tipis, kekanak-kanakan, dan menilai segala hal melalui materi, namun dibalut pakaian warna-warni, yang justru kurang mencitrakan kewibawaan. Karakter orang-orang desa dicitrakan penuh tawa, juga letih namun memiliki raut serius, kokoh dan pakaian lusuh. Visualisasi tersebut menambah dimensi kritis dalam menyampaikan ketimpangan sosial yang terjadi masa itu. Menurut penggambaran karakter desa-kota dari sisi sosiologisnya, karya ini cenderung memihak pada masyarakat desa yang sesuai dengan tema karya aslinya yaitu "antikemapanan" yang merujuk pada konsep $w a b i{ }^{\text {xii }}$ pada Zen. Adapun karakter Buddha sebagai simbol pencerahan ditampilkan pada babak terakhir.

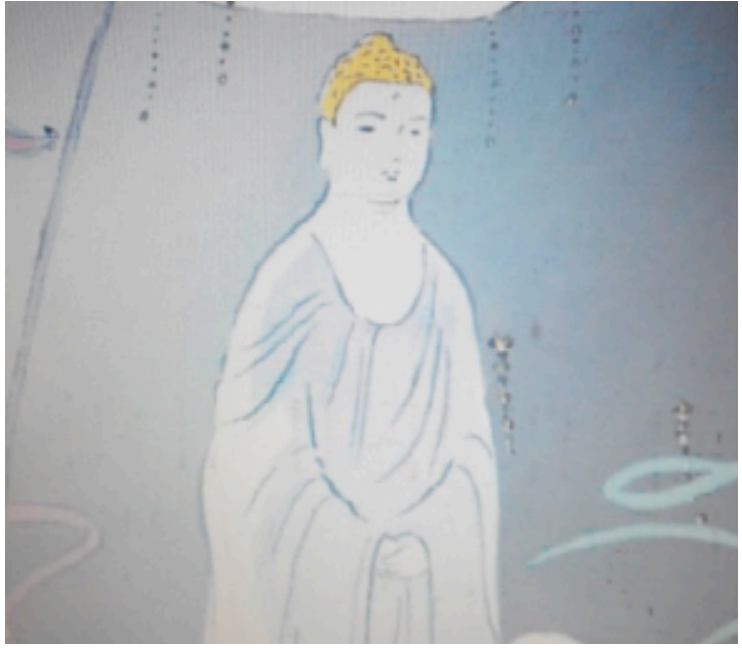

Gambar 19 Adegan Buddha datang menjemput Kaguya

Sumber : dokumentasi pribadi

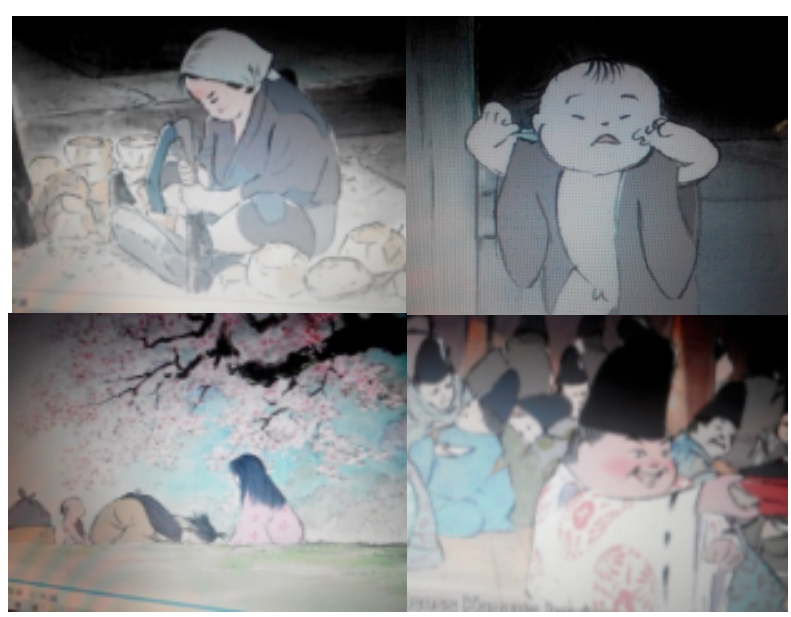

Gambar 20 (atas-bawah) Penggambaran fisik dan perbedaan kaum desa dengan kaum bangsawan dilihat dari kabiasaannya. (kiri-bawah) orang desa wajib memohon ampun pada kaum bangsawan atas kesalahan yang "tidak" mereka perbuat. Posisi kaum miskin selalu ditunduk di bawah kekuasaan. Sumber : dokumentasi pribadi

Penggambaran tokoh antagonis dan protagonis tidak disampaikan secara gamblang. Hal itu ditentukan oleh persepsi penonton, pandangan mana yang sependapat? Maka persepsi perilaku yang baik dan buruk bisa menjadi terbalik. Masingmasing karakter membawa kebenarannya 
sendiri, yang menjadi gambaran beragam karakter masyarakat saat ini. Sebagai contoh karakter Kakek dan Nenek menggambarkan bagaimana manusia menjaga berkah dengan cara yang berbeda. Penggambaran semacam ini memberi ruang refleksi dan imajinasi penonton tentang sebab akibat, tanpa terkesan memaksakan sebuah kebenaran.

\section{Shizen dalam Penciptaan Gerak: refleksi memori tubuh}

Gerak adalah faktor penting dalam studi animasi yang sangat bergantung pada sensibilitas animator. Sensibilitas dalam menciptakan gerak terbentuk dengan pengalaman animator. Norman McLaren menegaskan bahwa animasi bukan sekedar gambar yang berkerak tapi karya seni gerak yang digambarkan. Maka gerak menjadi nyawa sebuah karya animasi.

Sebagai karya animasi 2D, film ini masih menggunakan metode gerak frame to frame dengan teknik gambar manual (handdrawing). Menurut Walt Disney untuk menghasilkan gerak yang hidup adalah dengan bercermin pada alam dengan sifatnya yang faktual xiv. Prinsip tersebut juga dilakukan dalam Studio Ghibli yang selalu merujuk pada alam sekitar. Meski visualisasi karakter sederhana, Isao Takahata tetap menghadirkan gerak serealis mungkin. para animator diajak untuk mendalami gerak dalam suatu scene melalui pengamatan gerak serupa dalam keseharian maupun dipraktekkan langsung oleh si animator. Takahata juga mengajak mereka untuk mengingat masa kanak-kanak untuk dapat menghadirkan sendiri atmosfer gerak yang dimaksud si sutradara. Hal tersebut adalah upaya mengasah sensibilitas animator melalui memori tubuh.

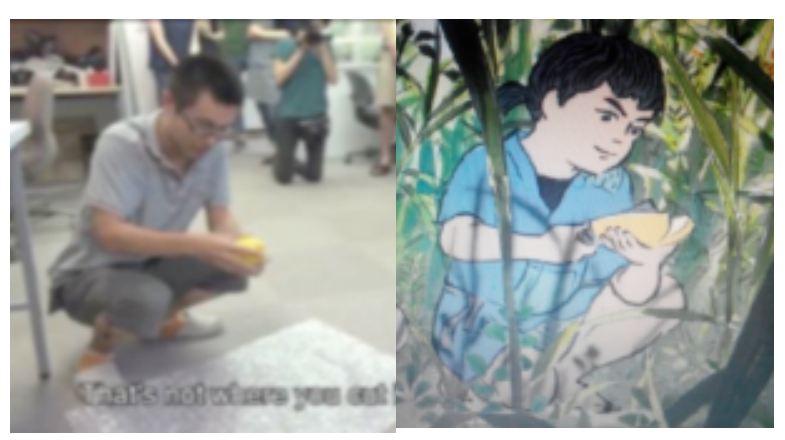

Gambar 21 Pembuatan detail gerak adegan mengiris buah dipraktekkan langsung oleh para animator sampai berulang kali.

Sumber : Ghibli Studio Behind the Scene Kaguya Hime

Metode tersebut menguatkan beberapa prinsip gerak animasi dalam karya ini antara lain : 1) slow in and slow out dan 2) secondary action yang memunculkan kesan alamiah, 3) straight ahead action and pose to pose dihadirkan pada beberapa adegan sebagai unsur visual storytelling, 4) follow trough and overlaping action pada rambut dan kain, 5) $\operatorname{arcs}^{x v}$ terutama pada gerak karakter wanita dan hewan. Kesemuanya menjadikan kesan gerak lembut, alamiah, dan detail.

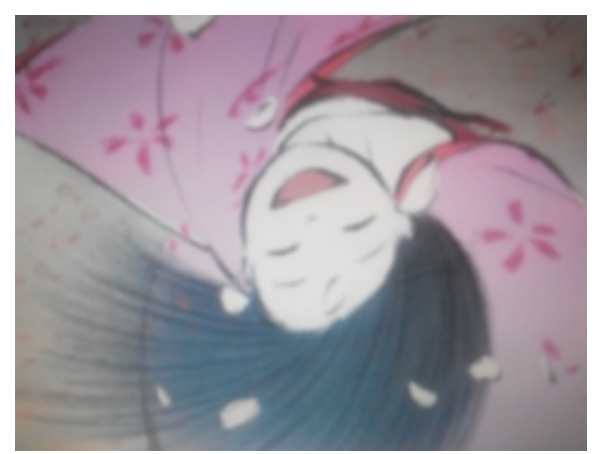

Gambar 22 Contoh penerapan prinsip gerak arcs. Sumber : dokumentasi pribadi

Shizen dalam perspektif seni merupakan keadaan dimana si seniman menyatu dengan karyanya. Dalam konteks ini 
seniman adalah para animator dan karyanya adalah scene yang dikerjakan. Memori tubuh yaitu bagaimana tubuh merekam kebiasaan atau suatu peristiwa gerak, nuansa, yang melibatkan sebagian atau seluruh panca indera. Hal itu mendukung dalam proses handdrawing karena gerakan dan memori langsung disampaikan melalui otot-otot tangan, sehingga sensibilitas gerak dapat lebih tersampaikan daripada dengan teknologi digital, gerak yang dihasilkan lebih alami. Teknik handdrawing dan memori tubuh menciptakan keintiman dalam praktek kerjanya sehingga menghapus jarak antara si seniman dan karyanya. Dari situ shizen dimunculkan sebagai peristiwa.

\section{Eksagerasi}

Eksagerasi merupakan sifat melebihlebihkan sesuatu dalam seni. Hal ini dimaksudkan supaya kesan pada peristiwa seni tersebut lebih tertangkap maupun lebih terasa dalam benak penikmatnya. Eksagerasi pada karya ini masih berada dalam jalur realisme. Sebagai karya adaptasi, eksagerasi menjadi unsur dramatisasi. Beberapa adegan menggunakan eksagerasi sebagai bumbu humor untuk meringankan adegan yang mengerikan, berat, atau sedih sehingga meminimalisir unsur kekerasan sebagai upaya menjaga etika film animasi ${ }^{9}$. Dalam beberapa adegan, eksagerasi menjadi bentuk ekspresi perasaan tertentu, di antaranya kekhawatiran, kegembiraan, jatuh cinta, ketergesaan dan sebagainya.

${ }^{9}$ Terdapat aturan dalam film animasi anak-anak dan remaja, antara lain tidak memperlihatkan darah dan adegan kekerasan yang terlalu vulgar.
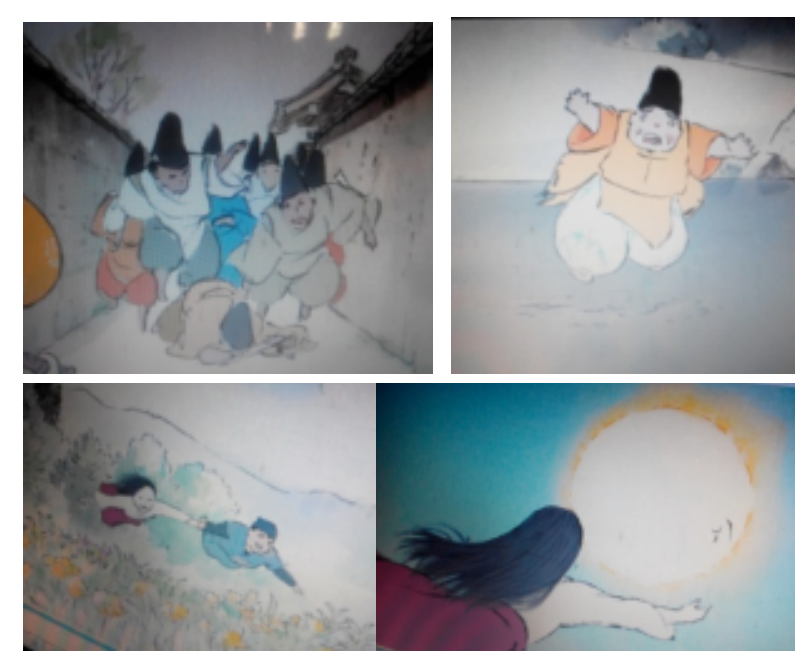

Gambar 23 Unsur eksagerasi pada beberapa adegan. Sumber : Dokumentasi pribadi

Eksagerasi sebagai ekspresi dramatis dekat dengan ciri datsuzoku yaitu tidak terbelenggu pada aturan yang berlaku, yang dalam konteks bahasa ungkap, bahasa Zen melampaui aturan bahasa umum ${ }^{\mathrm{xvi}}$. Eksagerasi pada karya ini memberi kejutan pada imaji penonton, yang menjadi sentuhan daya magis pada atmosfer karya yang berat dan sendu.

\section{Ekspresi Garis}

Wabi-sabi dalam konteks bahasa visual diartikan sebagai sapuan minimalis. Wabisabi pada benda-benda seni memberi kesan kering, tua, antik. Begitupun appeal visualisasi karya ini seolah melihat lukisan tradisional Jepang, karya lawas, antik.

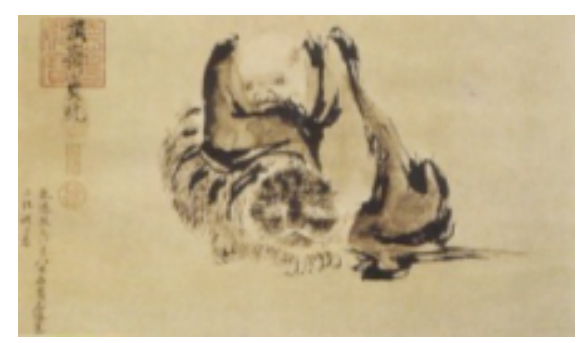

Gambar 24 Contoh lukisan Zen Shi K'o, Zen Master and a Tiger karakter. Sumber : www.wikipedia.org 
Adanya ekspresi garis sapuan kuas sebagai outline menguatkan sisi alamiah, kemanusiawian, ketidaksempurnaan, kejujuran, dan sensibilitas. Takahata menyebutkan bahwa ketidaksempurnaan ini merawat passion xvii dalam mengisi ruang pengkaryaan (timming dan scene), sehingga semangatpun masih terjaga. Sapuan kuas tentunya tidak dapat diulang dan tidak dapat digandakan. Kecenderungan itu memposisikan sapuan garis sebagai peristiwa, "yang terjadi saat ini" yang merujuk pada waktu (sabi).

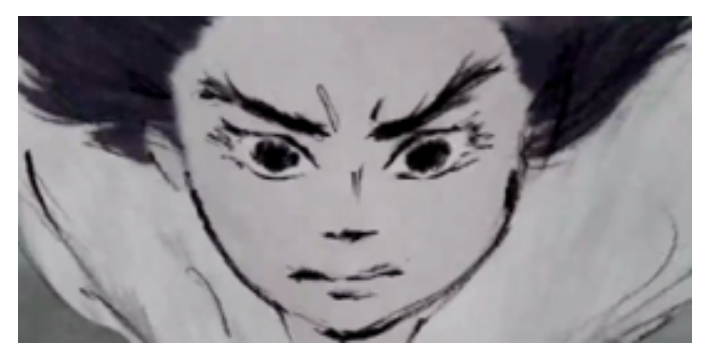

Gambar 25 Fungsi garis ekspresif untuk menguatkan ekspresi karakter. Sumber : Koleksi pribadi

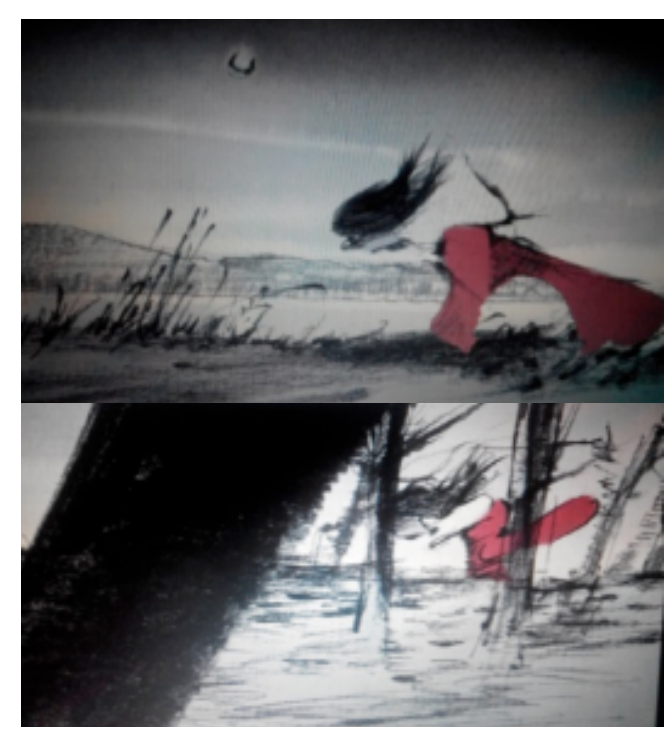

Gambar 26 Perubahan sapuan garis pada pergerakan karakter. Sapuan bebas pada objek background memperkuat sekaligus membingkai kesan kecepatan gerak karakter. Sumber : Koleksi pribadi
Penerapan sapuan garis membentuk fungsi garis sebagai penguat mimik, gestur, dan atmosfer yang dibangun pada suatu adegan. Garis bukan sekedar pembingkai namun menjadi bahasa visual. Fungsi garis sebagai bahasa menempatkan ekspresi garis pada ciri datsuzoku yaitu bebas dari belenggu aturan, sekaligus tidak mengejar kesempurnaan atau presisi yang merujuk juga pada unsur fukinsei (asimetris), garis menjadi keganjilan sekaligus sentuhan personal yang khas dalam tiap adegan dan tiap karakter. Melalui wabi-sabi, datsuzoku, fukinsei yang ada dalam garis, maka garis dapat dimaknai sebagai ekspresi kemanusiawian.

\section{Warna dan background}

Selain garis, warna dan background merupakan unsur penting yang memberi kedalaman pada karya animasi. Ada beberapa warna utama dalam karya ini yang memiliki fungsi sebagai ekspresi,vdan makna simbolis merujuk pada budaya Jepang, yaitu: 1) Midori (hijau): kesopanan, alami, terdapat pada background alam pepohonan dan kostum Kaguya masa dewasa awal; 2) Aoi (biru): ketenangan, langit, dan pikiran luas,; 3) Akai (merah): kekuatan, tanda dimulainya obsesi (vermilion), api yang merujuk pada amarah; 4) Kiiro (kuning): kebahagiaan, harapan; 5) Shiroi (putih): kesucian, ketulusan, salju, menjadi warna kulit Kaguya saat dewasa dan pendar cahaya bulan; 6) Hai iro (abu-abu): murung, debu, keseimbangan; 7) Pinku (pink) : perempuan, bersemi, cinta; 8) Kuroi (hitam): tabu, harga diri, kedalaman; 9) Cha iro (cokelat): kayu, ketenangan, ramah, setia. 


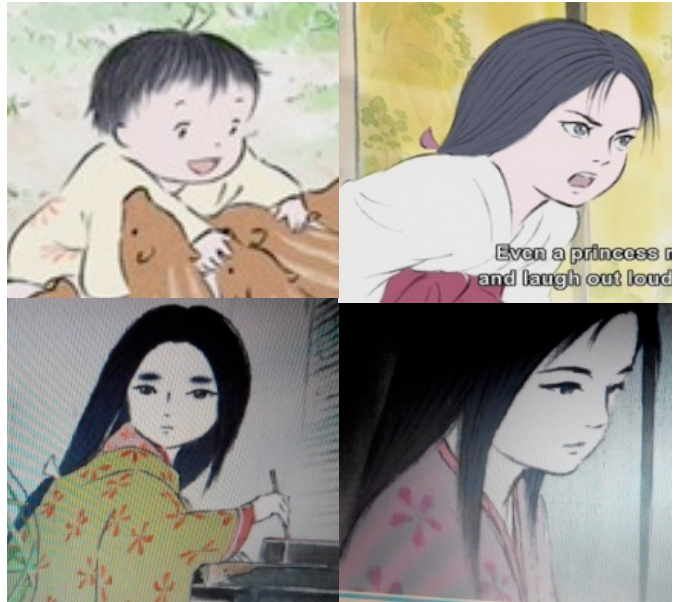

Gambar 27 Perubahan warna kostum Kaguya sesuai dengan perubahan konsep karakter. Sumber: Koleksi pribadi

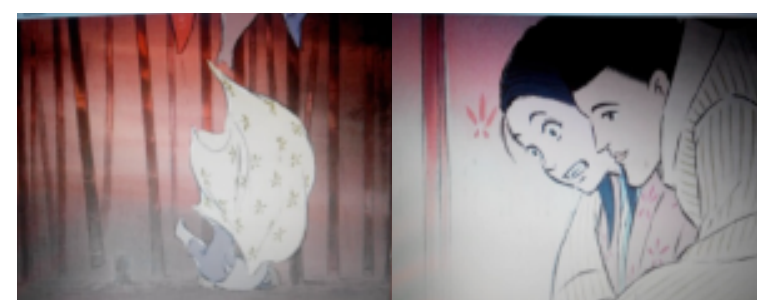

Gambar 28 Warna merah sebagai obsesi (kiri) dan kemarahan (kanan). Sumber: Koleksi pribadi
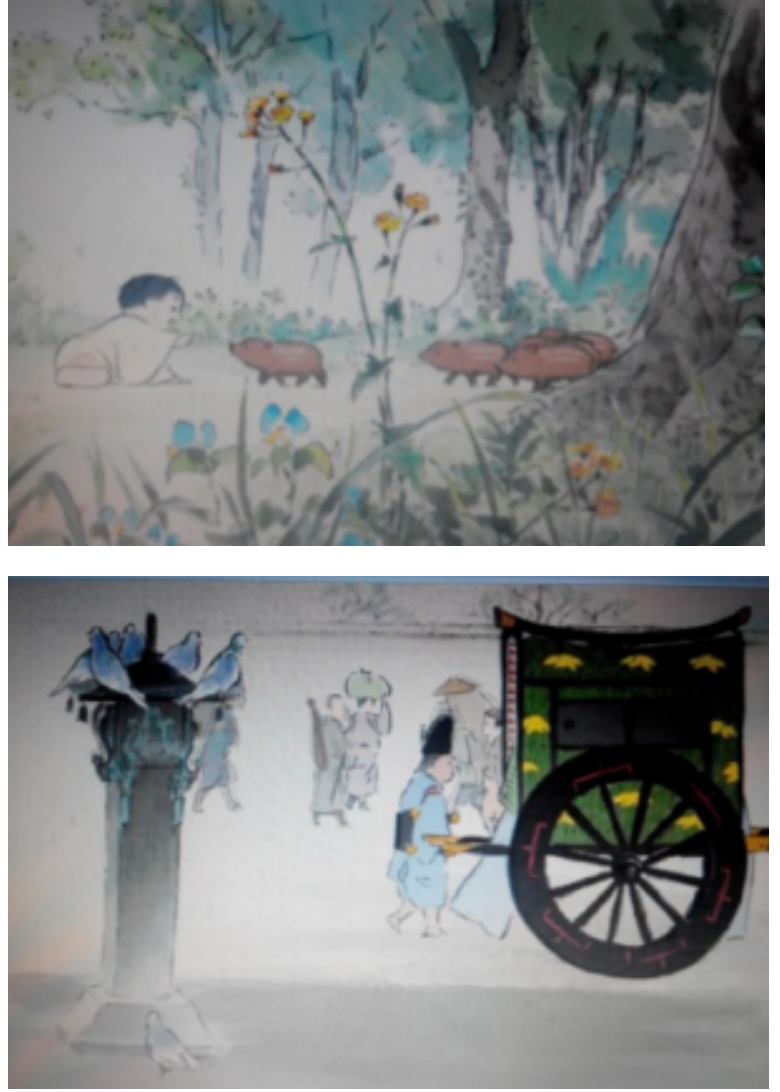

Gambar 29 (Atas) background desa yang detail, (bawah) background kota yang minimalis . Sumber: Koleksi pribadi

Penggambaran background menonjolkan sapuan cat air yang impresif dan berwarna opaque seperti seni lukis Zen. Berakar dari hakekat hidup Zen adalah keakraban dengan alam semesta, visualisasi background kota yang minim obyek dapat dimaknai hal yang semu, hampa, menguatkan gerak-gerik orang kota dengan kostum warna-warni, menandakan kota adalah wujud dari ego dan hukum manusia yang selalu menuntut kesempurnaan. Warna tembok yang dominan gradasi abu-abu memberi kesan batas yang dalam, kesunyian merujuk pada kondisi psikis Kaguya yang terkurung. Desa dan pegunungan didominasi warna cerah, hijau yang berkesan teduh, ceria dan bersahaja, dikombinasikan warna kostum 
karakter bernuansa coklat dan biru tua yang menyatu dengan warna background adalah hakekat kehidupan yang sesungguhnya, yaitu keakraban dengan alam yang menjadi masa joy of life Kaguya.

Penerapan teknik sapuan tipis warna menghadirkan unsur yuugen (kedalaman dan kehalusan) yang membingkai adegan dan karakter yang digambarkan ekspresif. Background yang sederhana memberikan fokus lebih pada aktifitas karakter, background dan warna berfungsi membentuk atmosfer dan dimensi makna pada adegan, dan memberi makna simbolis pada karakter. Garis yang ekspresif dan sapuan warna yang halus adalah bentuk kekontrasan yang saling menyeimbangkan keseluruhan karya, sehingga nampak sebagai kesatuan harmonis . Aktivitas karakter menjadi titik esensial dari kedalaman background yang berarti segala hal yang terjadi di dunia ditentukan oleh tindakan manusia.

\section{ZEN- SATORI DARI SEBATANG BAMBU}

“....birds, bugs, bees, grass, flowers and trees teach people how to feel...."

Tembang yang sering muncul dalam film animasi ini adalah gambaran bahwa hakekat kehidupan di alam semesta ini bersifat holistik. Kesadaran holistik itu adalah satori. Satori berarti terbangunnya kesadaran, perasaan bahwa tidak ada yang berdiri sendiri di alam semesta ini dan mengarah pada simpati yang luas. Satori muncul secara tibatiba berupa pengalaman sesaat namun pengaruh pencerahannya tidak bersifat sesaat.

Berdasarkan Zen ${ }^{\text {xviii }}$, konsep Kaguya adalah gambaran siklus hidup bambu sebagai laku hidup, Kaguya yang berarti cahaya bersinar dari sebatang bambu merupakan metafora kesakralan sebatang bambu. Bambu di Jepang menjadi tanaman rakyat,simbol kesederhanaan. Dari awal bambu tumbuh hingga menua, ia banyak memberi daya hidup dan pertolongan bagi makhluk di sekitarnya. Bambu yang baik tumbuh secara wajar dan alamiah tanpa ada campur tangan manusia. Dari sifat-sifat tersebut, esensi dari bambu adalah kehidupan sederhana yang menghidupi sekitarnya.

Keseluruhan perjalanannya di film ini dapat dimaknai sebagai proses meditasi yaitu proses dialektis dan perjumpaan dengan segala unsur dalam diri. Jiwa yang belajar disimbolkan semurni bayi yang menyerap pengetahuan murni dari alam dengan polosnya dan tumbuh bersama pikiran dan perasaannya. Adanya derita berasal dari perjumpaannya pada sifat amarah, kekuasaan, kekhawatiran, iri dengki, dendam, hasrat dan obsesi akan hal-hal diluar diri kita. Jiwa berevolusi sesuai dengan pencapaian kesadarannya melalui refleksi dan introspeksi dari berbagai tantangan dan masalah yang ada.

Bulan adalah lambang welas asih, yang mampu melepaskan manusia dari segala derita. Jiwa yang tentram adalah yang lepas dari kemelekatan, ego (keinginan diri), dan yang ada hanya kasih yang murni. Ibarat keluwesan bambu yang diolah menjadi berbagai macam bentuk, pada hakekatnya tetaplah bambu namun dengan identitas yang lain. ketika kita menuntut sesuatu dengan keharusan, maka kita tidak bisa bebas dari ego, pada dasarnya kebebasan itu sudah ada dalam diri masing-masing makhluk dan nilai darri sesuatu bukan berasal dari perbandingan dengan yang lain, namun terkandung dalam setiap ciptaanNya ${ }^{\text {xix }}$. Dari 
situ segala penolakan, derita yang datang tidak mempengaruhi ketentraman di jiwa dan malah dirasakan sebagai rupa-rupa kesadaran.

Dalam praktek Buddha Shakyamuni ada 4 penderitaan dasar yang menyebabkan kebingungan dalam hidup, yaitu: 1) perpisahan dengan mereka yang kita cintai, 2) kebersamaan dengan orang yang kita benci, 3) kenyataan bahwa kita tidak dapat memiliki apa yang kita inginkan, 4) kenyataan bahwa tubuh fisik merupakan bejana penderitaan. Keempat penderitaan tersebut dapat disaksikan pada beberapa adegan dalam karya animasi ini.

Ketika mengalami satori bukan berarti segala penderitaan atau masa lalu sepenuhnya dilupakan, selama kita hidup hal itu tetap ada sebagai bagian dari perjalanan hidup, yang berbeda adalah cara menghadapinya. Hal ini disimbolkan pada adegan terakhir ketika Kaguya menengok ke bumi saat kembali ke bulan.

Kaguya mendapatkan 2 kali satori yaitu tentang ketidakkekalan dan tentang rasa hidup. Yang menghubungkan setiap makhluk semesta adalah rasa hidup, bukan obsesi atau pikiran. Ibarat ruas-ruas bambu, dari situ seseorang merasa bahwa ia adalah wadag (kosong) yaitu kondisi dimana keakuan (ego) tidak ada, kita menjadi sama dengan segala makhluk di bumi. Tidak ada yang paling rendah atau tertinggi, semua saling membutuhkan dan terus berubah.
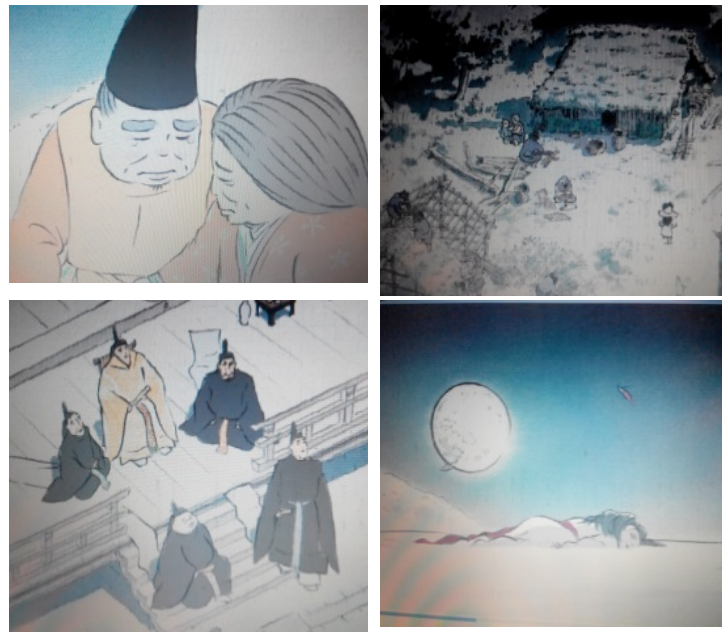

Gambar 30 Simbol 4 penderitaan dasar. (Kiri atasbawah) cinta dan benci. (kanan atas-bawah) keinginan dan realitas.

Sumber : Koleksi pribadi

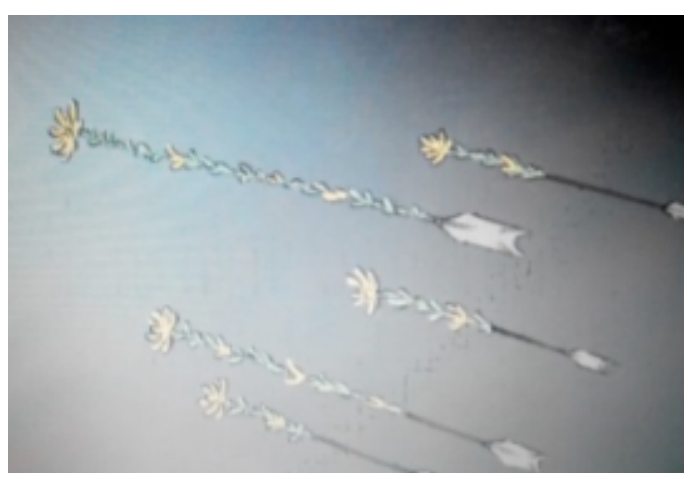

Gambar 31 Simbol belas kasih. Anak panah diubah menjadi bunga. Sumber : Koleksi pribadi

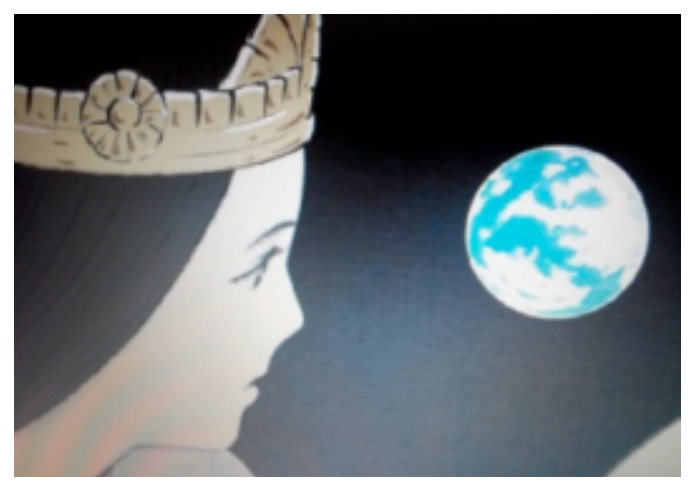

Gambar 32 Adegan Kaguya masih dapat mengingat bumi setelah mengalami pencerahan. Sumber : Koleksi pribadi 


\section{ANIMASI MENJAWAB PERSOALAN}

Karya animasi ini berhasil menyampaikan pesan yang berat menjadi ringan dengan mengangkat 2 elemen dasar senirupa menjadi pusat ekspresi yaitu sapuan garis dan warna. Namun atmosfer yang dalam justru mengurangi kekuatan humor. Sifat fukinsei (asimetris) pada karya seni modern justru memicu imajinasi dan eksplorasi yang cukup baik bagi seniman maupun penikmatnya.

Lewat karakter Kaguya, animasi ini menggambarkan tentang keadaan manusia yang terjebak dengan pikirannya (logika) yang tidak berjalan seimbang dengan kata hatinya sehingga rasa hidup menjadi hambar. Keadaan tersebut menjadi gambaran manusia saat ini baik di Jepang maupun dunia yang mendewakan pikiran, kesempurnaan, akhirnya terjebak dalam kekhawatiran dan keserakahan sehingga menilai alam bukan lagi sesuatu yang akrab dan sakral namun komoditas. Kritik sosial karya ini disampaikan melalui gambaran cara hidup yang berbeda. Lebih lanjut karya ini cenderung berpihak pada prinsip hidup masyarakat desa yang berbicara tentang rasa hidup kesederhanaan, bersahaja, keakraban antar manusia dan alam, yang menjadi ajaran dasar Buddhisme. Karya ini membuktikan bahwa segala elemen animasi mampu menyampaikan muatan nilai-nilai spiritual melalui nilai keindahannya.
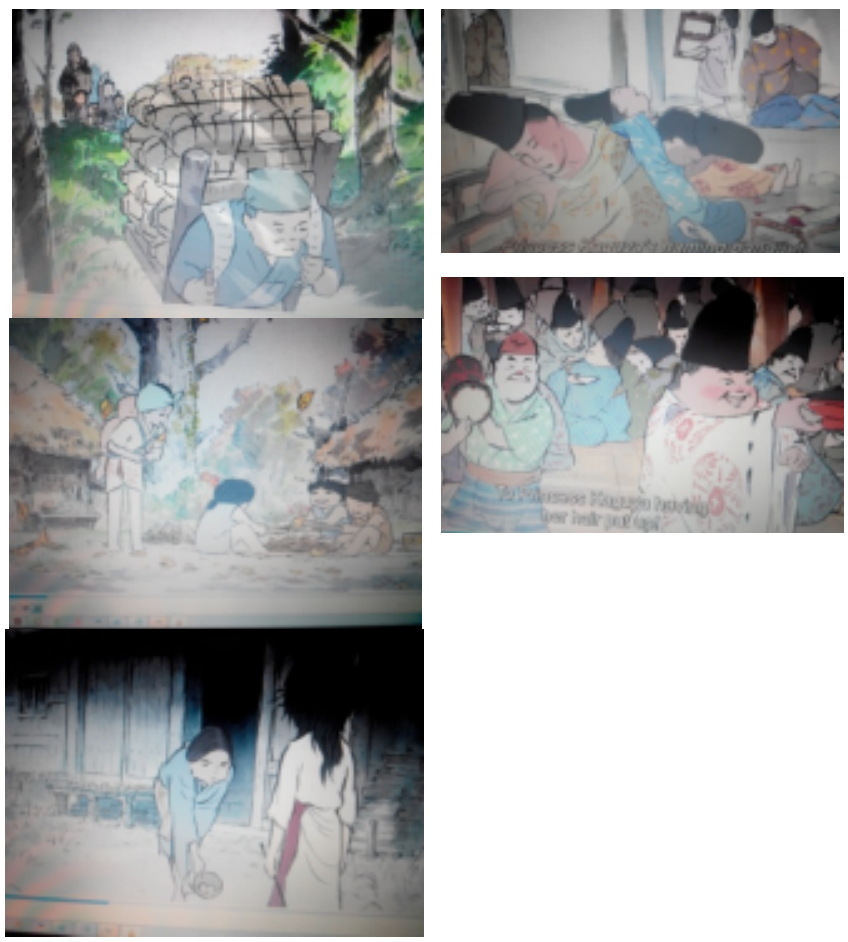

Gambar 33 Ilustrasi perbedaan kehidupan desa (kiri) dan kota (kanan). Sumber: dokumentasi pribadi

\section{DAFTAR PUSTAKA}

[1] Ali Matius, ESTETIKA: Pengantar Filsafat Seni, Sanggar Luxor, 2011.

[2] Darsono, Estetika, Bandung, Rekayasa Sains, 2007.

[3] Harada Sekkei, Hakikat Zen: Jalan Spiritual Menuju Diri Sejati, Jakarta, PT. Gramedia Pustaka Utama, 2003.

[4] Hutcheon Linda, A Theory of Adaptation, New York-London, Routledge, 2006.

[5] Prakosa Gotot, Animasi; Pengetahuan Dasar Film Animasi Indonesia, Jakarta, FFTV-IKJ dan Yayasan Seni Visual Indonesia, 2010.

[6] Rastati Rani, Analisis Penggunaan Warna Maskulin dan Feminin pada Hadiah Ulang Tahun Anak-anak Jepang, Tugas Akhir Skripsi, Jakarta, FIB-UI, 2008. 
[7] Sachari Agus, Pengantar Metodologi Penelitian Budaya Rupa: Desain, Arsitektur, Seni Rupa dan Kriya, Jakarta, Penerbit Erlangga, 2005.

[8] Sutrisno S.J., F.X. Mudji, Estetika: Filsafat Keindahan, Yogyakarta, Kanisius, 1993.

\section{WEBSITE}

[1] www.studioghibli.com

[2] www.asianwikki.com

[3] www.celestialkitsune.wordpress.com

[4] www.guntarmanbeni.wordpress.com

[5] www.wikipedia.org

\section{VIDEO}

[1] Ghibli Studio, The Tale of Princess Kaguya.

[2] www.youtube.com

[3] Anime Everyday, The Tale of Princess Kaguya- Kaguya's Breakdown, 2015.

[4] Movieclips Extras, The Tale of Princess Kaguya Behind the Scenes-looking for Reality (2014)-Animated Movie HD, 2014.

[5] Movieclips Extras, The Tale of Princess Kaguya Behind the Scenes- Beyond Traditional Animation (2014)-HD, 2014.

[6] Movieclips Extras, The Tale of Princess Kaguya Behind the Scenes-Composer Joe Hisaisi (2014)-Animated Movie HD, 2014.

[7] NHK Begin Japanology Plus ,Bamboo, 2008.

[8] NHK Begin Japanology Plus, The Season, 2010.

[9] NHK Begin Japanology Plus, Wagashi, 2010.

[10] Studio Ghibli, The Birth of Studio Ghibli part 1-3.

\section{Catatan Akhir}

i Sachari Agus, Pengantar Metodologi Penelitian Budaya Rupa: Desain, Arsitektur, Seni Rupa dan Kriya, Jakarta, Penerbit Erlangga, 2005, h. 119.

ii Ibid, h.129.

iii Sutrisno S.J., F.X. Mudji, Estetika: Filsafat

Keindahan, Yogyakarta, Kanisius, 1993, h.118.

iv Ali Matius, ESTETIKA : Pengantar Filsafat Seni, Sanggar Luxor, 2011, h. 162.

${ }^{\vee}$ Estetika Zen pada Esensi dan Filosofi Haiku, www.guntarmanbeni.wordpress.com

${ }^{\mathrm{vi}}$ Lihat Estetika Buddhisme dalam Darsono, Estetika, Bandung, Rekayasa Sains,2007, h. 102-103.

vii Lihat video The Birth of Studio Ghibli part 2.

viii Prakosa Gotot, Animasi; Pengetahuan Dasar Film Animasi Indonesia, Jakarta, FFTV-IKJ dan Yayasan Seni Visual Indonesia, 2010, h.321.

ix Lihat Telling-Showing dalam Hutcheon Linda, A Theory of Adaptation, New YorkLondon, Routledge, 2006, h.39-40. Unsur dramatisasi dicontohkan melalui pertunjukan drama musikal dan film yang menekankan gerak,mimik, gesture, unsur musikal seperti irama, ritme, komposisi dll sebagai pemicu hasrat penonton dalam menikmati karya.

${ }^{x}$ NHK Begin Japanology Plus Bamboo.

${ }^{x i}$ Lihat video NHK Begin Japanology Plus The Season.

xii ..Takahata said "That's right i'm drawing a selfish girl. Selfishness is the characteristic of the modern girl, isn't it? I don't intend to just draw and old tale. What will a modern girl who time traveled to the Heian era do there? I thought that it is a big theme to see it." , Behind the Scene The Tale of Princess Kaguya, Studio Ghibli

Dalam www.celestialkitsune.wordpress.com 
xiii Merujuk pada Ali Matius, ESTETIKA : Pengantar Filsafat Seni, Sanggar Luxor, 2011, h. 160. Wabi dalam seni maupun kehidupan dimaknai sebagai menjadi miskin, atau kesederhanaan dalam hidup. Sesuai dengan ajaran Buddha yaitu bebas dari kemelekatan, dan ego, wabi melihat keindahan melalui halhal yang sederhana, tidak semarak maupun mencolok, namun justru mengarah pada hakekat hidup melalui keakraban pada alam semesta (sabi).

xiv Prakosa Gotot, Animasi; Pengetahuan Dasar Film Animasi Indonesia, Jakarta, FFTV-IKJ dan Yayasan Seni Visual Indonesia, 2010, h.163.

xv Ibid, h.159-165. 1) slow in and slow out: gerak melambat pada bagian awal dan melambat pada bagian akhir, 2) secondary action : detail gerakan yang dibuat untuk mendukung gerakan utama, 3) straight ahead action adalah cara menggambarkan gerak yang terus menerus tanpa terputus sehingga menciptakan gerak yang kontinu, pose to pose : gerakan kunci dari pose pertama ke pose selanjutnya, 4) follow trough and overlaping action: gerakan menyambung, yaitu ketika obyek utama memiliki bantak atribut yang ikut bergerak berkesinambungan dengan gerak obyek utama, 5) arcs : gerakan melingkar.

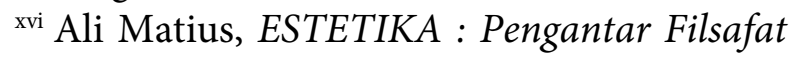
Seni, Sanggar Luxor, 2011, h. 169.

xvii www.celestialkitsune.wordpress.com

xviii Merujuk pada Harada Sekkei, Hakikat Zen : Jalan Spiritual Menuju Diri Sejati, Jakarta, PT. Gramedia Pustaka Utama, 2003, h.4-11. Zen dipahami sebagai jalan, yang pada essensinya adalah menjadi intim dengan Diri Sejati . Sebagaimana Sakyamuni, jalan pencerahan dicapai melalui aktifitas keseharian dan meditasi-Nya sendiri. Maka dapat dikatakan segala aktifitas manusia yang diniatkan ke arah transendental adalah bentuk meditasi. Salah satu tujuannya adalah menerima diri dan segala kepribadian diri. xix Ibid , h.10-11. 